WSRC-TR-2003-00238, Rev. 1

Keywords: Mercury Speciation Dimethylmercury Solubility Vapor Sampling

\title{
Studies of Mercury in High Level Waste Systems
}

W. R. Wilmarth

S. W. Rosencrance

C. E. Duffey

March 31, 2004

Page 1 of 33 
This document was prepared in conjunction with work accomplished under Contract No. DE-AC09-96SR18500 with the U. S. Department of Energy.

\section{DISCLAIMER}

This report was prepared as an account of work sponsored by an agency of the United States Government. Neither the United States Government nor any agency thereof, nor any of their employees, makes any warranty, express or implied, or assumes any legal liability or responsibility for the accuracy, completeness, or usefulness of any information, apparatus, product or process disclosed, or represents that its use would not infringe privately owned rights. Reference herein to any specific commercial product, process or service by trade name, trademark, manufacturer, or otherwise does not necessarily constitute or imply its endorsement, recommendation, or favoring by the United States Government or any agency thereof. The views and opinions of authors expressed herein do not necessarily state or reflect those of the United States Government or any agency thereof.

This report has been reproduced directly from the best available copy.

Available for sale to the public, in paper, from: U.S. Department of Commerce, National Technical Information Service, 5285 Port Royal Road, Springfield, VA 22161, phone: (800) 553-6847, fax: (703) 605-6900

email: orders@ntis.fedworld.gov

online ordering: http://www.ntis.gov/help/index.asp

Available electronically at http://www.osti.gov/bridge

Available for a processing fee to U.S. Department of Energy and its contractors, in paper, from: U.S. Department of Energy, Office of Scientific and Technical Information, P.O. Box 62, Oak Ridge, TN 37831-0062,

phone: (865)576-8401,

fax: (865)576-5728

email: $\underline{\text { reports@ adonis.osti.gov }}$ 


\section{Executive Summary}

Historically, mercury was added to the nuclear weapons processing as a catalyst for the dissolution of aluminum metal. After neutralization the mercury was disposed to the High Level Waste tanks where its speciation led to mercuric oxides/hydroxides in the sludge and a small soluble mercuric ion concentration in the alkaline supernate. This report in its original revision described a three-pronged approach for studying possible sources of elevated mercury vapor in and around the Tank Farm evaporator systems. This approach examined the engineering differences between the evaporator designs, the chemistry of mercury and its concentrations, and the potential for organomercury species.

During the course of this work, the presence of dimethylmercury in the High Level Waste system was established. Vapor and liquid samples were analyzed from the three evaporator systems $(2 \mathrm{H}, 2 \mathrm{~F}$, and $3 \mathrm{H})$ along with the transfer lines leading to the Effluent Treatment Facility (ETF) and tanks within the ETF. The magnitude of the dimethylmercury concentrations led to ventilation modifications at the $3 \mathrm{H}$ Evaporator and design for modifications at the $2 \mathrm{H}$ evaporator. Continued sampling efforts are aimed at understanding the boundaries of where dimethylmercury vapors exist.

In the original version of this report (rev. 0), the initial testing conducted at Frontier Geosciences, Seattle, WA was presented where research into the formation of dimethylmercury showed that several organic components readily formed dimethylmercury under elevated temperatures in supernate simulants. Subsequently, two additional phases of testing were conducted. In the first of these phases, Frontier examined the decomposition of dimethylmercury in three different matrices ( $\mathrm{pH} 2 \mathrm{ETF}$ simulant, pH 10 overheads simulant and supernate simulant) at three temperatures. Decomposition half lives showed that at $\mathrm{pH} 10$ dimethylmercury was the most stable with $\mathrm{t}_{1 / 2}$ over 1 year at $40{ }^{\circ} \mathrm{C}$. The dimethylmercury half life at $\sim 80^{\circ} \mathrm{C}$ in a simulated supernate was 6.4 days.

The second phase of testing examined the formation of dimethylmercury in the same solution matrices and with four different organic constituents. The constituents were sodium acetate, antifoam (Dow Corning $\mathrm{H}-10$ ), an antifoam degradation product (trimethylsilanol) and permanganate-degraded ion exchange resin. The results of these tests showed that dimethylmercury would form from any of these organic components. For each set of conditions, the amount of $\left(\mathrm{CH}_{3}\right)_{2} \mathrm{Hg}$ production increased approximately linearly with time, and exponentially with increasing temperature. At any given temperature and time, the samples containing a mixture of methyl donors (the most potent of which is the antifoam agent polymethyldisiloxane) plus acetate generated approximately two orders of magnitude more $\left(\mathrm{CH}_{3}\right)_{2} \mathrm{Hg}$ than did the acetate alone. By the end of the experiment, a maximum of $2 \%$ of the total $\mathrm{Hg}$ initially present $\left(10 \mathrm{mg} \mathrm{L}^{-1}\right)$ had been converted to $\left(\mathrm{CH}_{3}\right)_{2} \mathrm{Hg}$ with the mixed organics incubated at $80^{\circ} \mathrm{C}$. Neither of the synthetic sludges was seen to have an effect of methylation in any of the experiments, indicating that the presence of these solids was not catalytic with respect to methylation 
or demethylation of Hg. These data will be used to interpret sampling data collected from the selected waste tanks and process vessels.

Since Revision 0 of this report, a significant amount of sampling and analysis for mercury and organomercury species has been conducted. Sampling campaigns have examined the vapor space of several High Level Waste tanks. Additional samples have examined the 2F Evaporator, ETF locations and the process sewer manholes leading to ETF. It is the intention of the authors to incorporate these data and the remainder of FY04 sampling results in a subsequent revision. 


\section{TABLE OF CONTENTS}

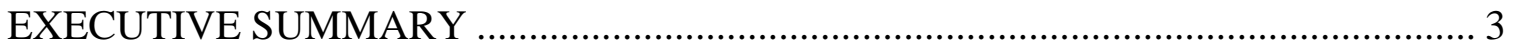

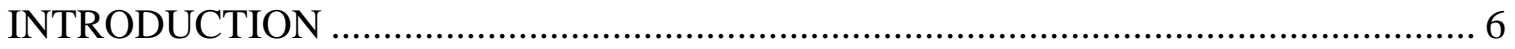

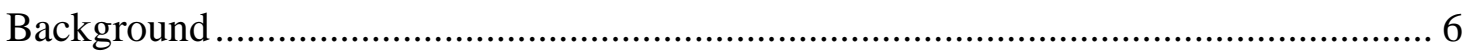

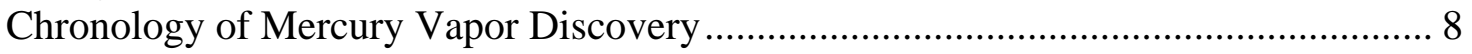

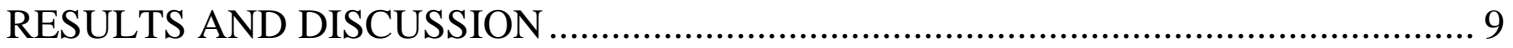

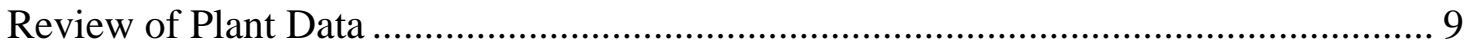

Review of Published Literature on Mercury Chemistry .......................................... 12

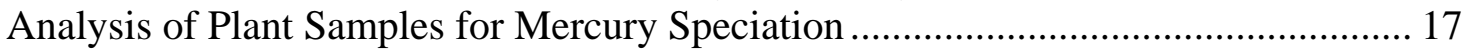

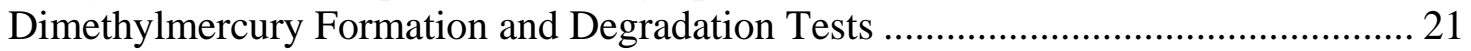

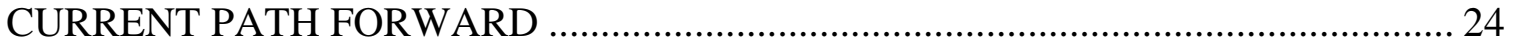

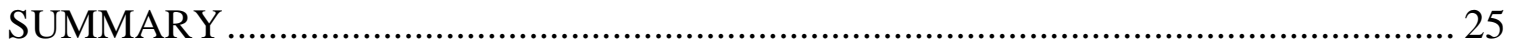

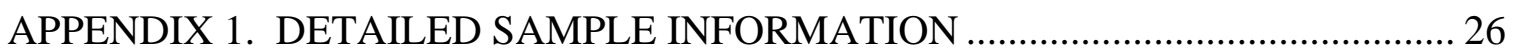

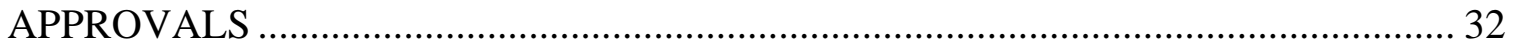

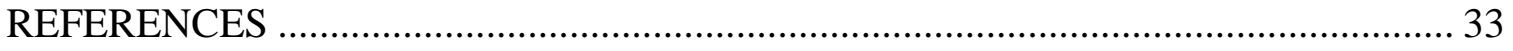

\section{LIST OF FIGURES}

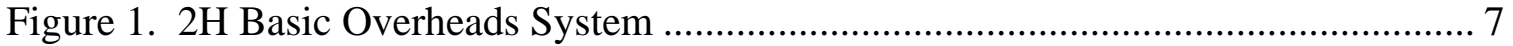

Figure 2. Mercury Vapor Pressure as a Function of Temperature................................ 10

Figure 3. Plot of Operational Data for 3H Evaporator................................................ 11

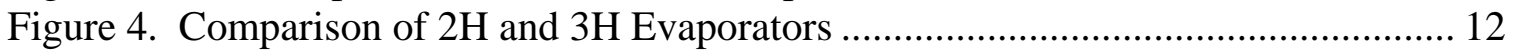

Figure 5. Distribution of Hydrolysis Products for Solutions Saturated with $\mathrm{Hg}(\mathrm{OH})_{2} . .13$

Figure 6. Mercury Concentration versus KOH Concentration ...................................... 14

Figure 7. OLI Predicted Solubility as a Function of Caustic Concentration and

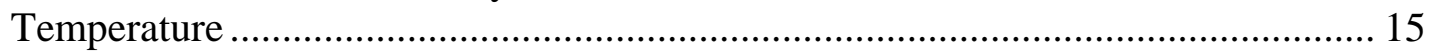

Figure 8. Mole Fraction of Elemental Hg in Condensate .......................................... 17

Figure 9. Summary of DMHg in Vapor and Liquid Samples....................................... 19

Figure 10. Dimethylmercury Reaction Vessel......................................................... 21

\section{LIST OF TABLES}

Table 1. SRS High Level Waste Evaporator Information ............................................ 9

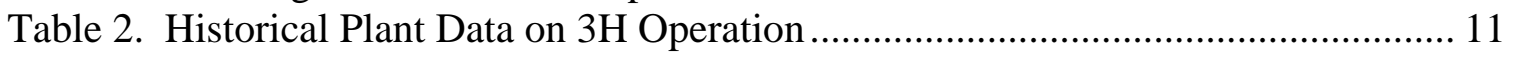

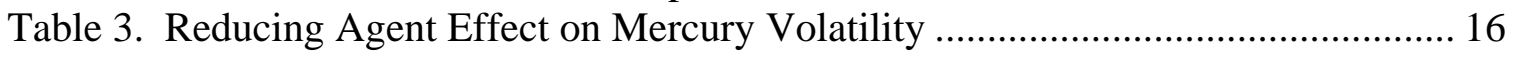

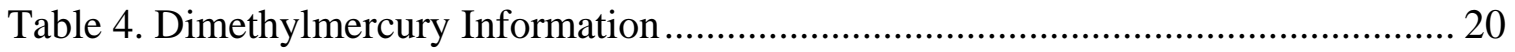

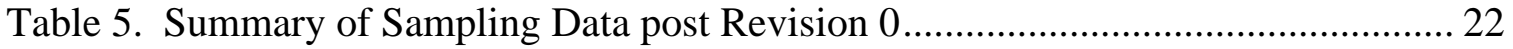

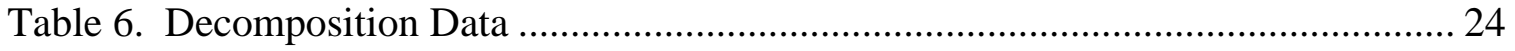




\title{
Studies of Mercury in High Level Waste Evaporator Systems
}

\author{
W. R. Wilmarth, S. W. Rosencrance and C. E. Duffey \\ Waste Processing Technology \\ Savannah River Technology Center \\ Westinghouse Savannah River Company
}

\section{INTRODUCTION}

\section{Background}

During nuclear weapons production, nuclear reactor target and fuel rods were processed in F- and H-Canyon, respectively. For the target rods, a caustic dissolution of the aluminum cladding was performed prior to nitric acid dissolution of the uranium metal targets in the large canyon dissolvers. The fuel rods consisted of a uranium-aluminum alloy and were processed in H-Canyon. To dissolve the aluminum cladding and the U-Al fuel, mercury in the form of soluble mercury (II) nitrate was added as a catalyst to accelerate the dissolution of the aluminum. During the late 1970's and 1980's, F-Canyon began to process plutonium-containing residues that were packaged in aluminum cans and thus required the use of mercury as a dissolution catalyst.

Following processing to remove uranium and plutonium using the solvent extraction process termed the Plutonium-Uranium Recovery by EXtraction (PUREX) process, the acidic waste solutions containing fission products and other radionuclides were neutralized with sodium hydroxide. Upon neutralization, two separate waste streams are created with the first being a transition metal-laden sludge and the second being a dilute supernate. The sludge/supernate slurry is discharged from the canyon facilities for storage in carbon steel tanks. The F- and H-Area tank farms consisted of 51 nominally 1 million-gallon tanks. In order to conserve tank space, the dilute waste supernate is evaporated. Historically, the waste was evaporated to the point that certain sodium salts (nitrate and nitrite) would crystallize into a saltcake in the drop tank.

The mercury used in canyon processing is fractionated between the sludge and supernate that is transferred from the canyons to the tank farm. The sludge component of the waste is currently vitrified in the Defense Waste Processing Facility (DWPF). The vitrified waste canisters are to be sent to the federal repository for High Level Waste. The mercury in the sludge, presumably in an oxide or hydroxide form $\left(\mathrm{HgO}\right.$ or $\left.\mathrm{Hg}(\mathrm{OH})_{2}\right)$ is reduced to elemental mercury by the chemical additions and high temperatures in the Slurry Receipt and Adjustment Tank (SRAT), steam stripped and collected in the Mercury Collection Tank. The mercury in the dilute supernate is in the form of mercuric ion $\left(\mathrm{Hg}^{2+}\right)$ and is soluble. During evaporation, the mercuric ion is reduced to elemental 
mercury, vaporizes into the overheads system and is collected as a metallic liquid in the Mercury Removal Tank shown schematically in Figure 1.

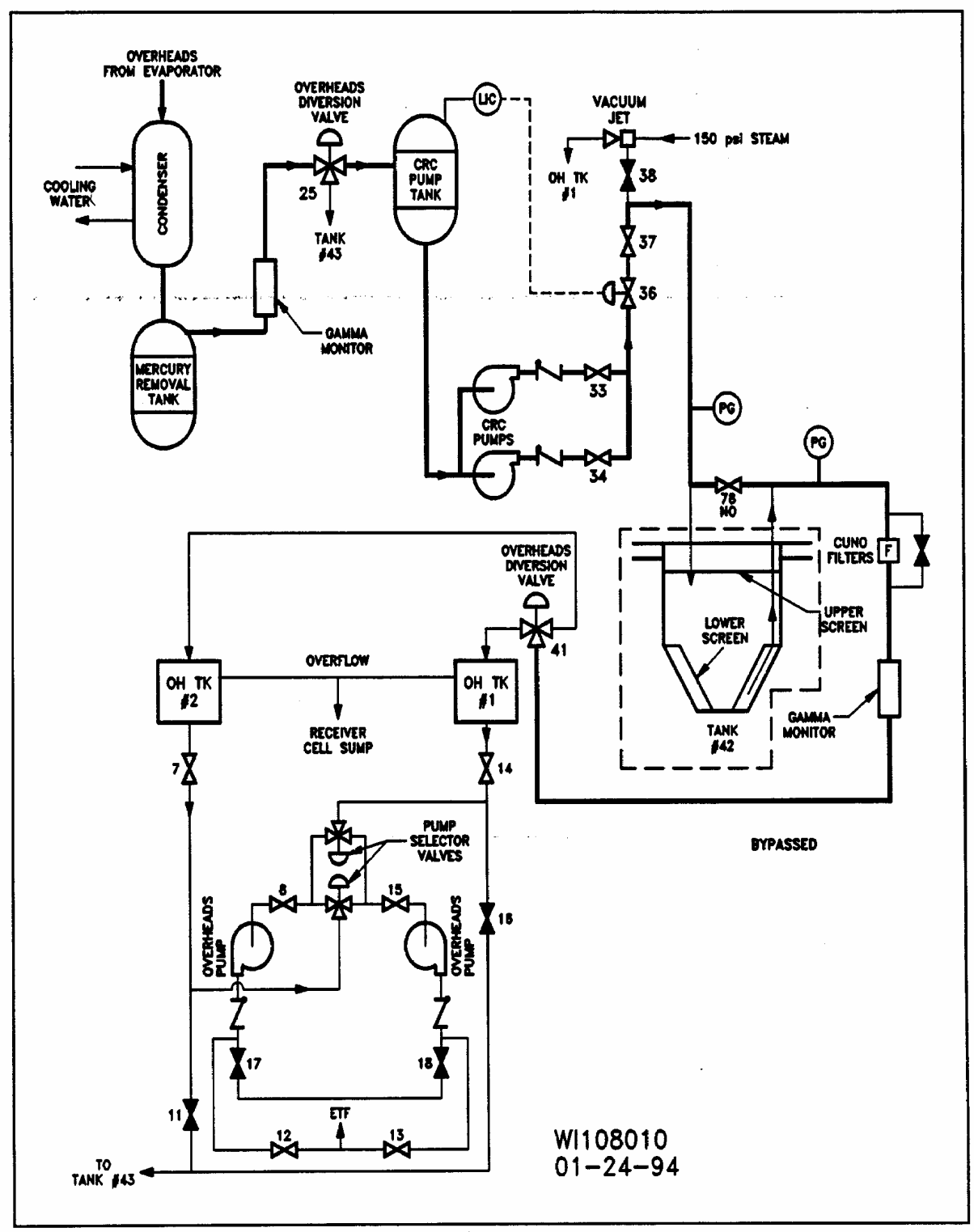

Figure 1. 2H Basic Overheads System

Currently the CRC column and Tank 42 equipment is by-passed 


\section{Chronology of Mercury Vapor Discovery}

During a startup of the 3H Evaporator in summer 2001, samples taken from the evaporator overheads and analyzed by the Effluent Treatment Facility (ETF) lab for mercury were found to contain mercury levels above the ETF Waste Acceptance Criteria (WAC) limit of $2 \mathrm{mg} / \mathrm{L}$. As a result of this, the $3 \mathrm{H}$ Evaporator was operated under a special procedure and deviation after July 13, 2001 to collect data to aid in understanding the high levels of mercury in the overheads. Based on the data collected, it was determined that the high mercury levels were probably the result of high mercury concentrations in the feed and high steam flow rates (high temperatures) in the evaporator. During this testing, a quarterly sample was transported to the Savannah River Technology Center (SRTC) to be checked for compliance with the WAC. The mercury analysis gave a result approximately 1/50th of that found by the ETF lab in a sample pulled during the same week. Discussions were initiated, and it was noted that while both labs used essentially the same analytical method (atomic absorption) SRTC had not been digesting the mercury samples prior to analysis whereas the ETF lab had been. SRTC had believed that since the samples contained primarily distilled water and showed little signs of contamination, especially with organics, that digestion of the mercury was unnecessary. A round-robin test was run with SRTC, ETF and Central Lab in F Area analyzing the same sample. This time all labs digested the mercury samples prior to analyzing and obtained similar results. From this it was concluded that even the very small amount of organic contamination found in the samples (on the order of 10 - 20 $\mathrm{mg} / \mathrm{L}$ ) was sufficient to complex the mercury and interfere with analysis.

Also in June of 2001, elevated levels of mercury vapor were discovered in the 3H Evaporator service building during a routine survey. These elevated levels were not expected based on the process model for the system and experience with operating other waste evaporators on site. The higher concentrations of mercury vapor were recorded in the overheads cell area. Speculation on why the elevated mercury levels were found in the $3 \mathrm{H}$ system and not the $2 \mathrm{H}$ system suggested several design and operational differences. SRTC was requested to examine the chemistry of mercury in support of issue resolution.

As will be described in detail in other parts of this report, liquid samples of the evaporator overheads were analyzed to better understand the mercury vapor results. Analysis of the liquid overheads samples determined the presence of both elemental and organomercury species. The presence of organomercury species in the liquid was unexpected.

Controls were put in place to protect the workers from the elemental mercury vapors and a program was developed to better understand the organomercury species. At the time, there was no routine method available to detect organomercury vapors. An outside laboratory, with extensive experience in measuring low levels of organomercury in vapors and liquids, was contracted to assist with developing a sampling plan to measure concentrations of organomercury in the $3 \mathrm{H}$ Evaporator service building.

The intent of this report is to document the systematic review of mercury chemistry that assisted in resolving and identifying mercury issues associated with the High Level 
Waste system. The report will be revised as new information is obtained. This report also partially fulfils requests made by the Closure Business Unit. ${ }^{1}$

\section{RESULTS AND DISCUSSION}

Once the mercury concentrations in the overheads liquids were confirmed by the Effluent Treatment Facility (ETF) and the Savannah River Technology Center, the focus shifted to understanding the reasons for elevated mercury concentrations in the overhead tank's liquid and the service building's vapor space. SRTC began to explore four avenues to resolve the mercury issues. These are listed below:

- Review of Plant data for insight into mercury behavior

- Examine known information on the caustic behavior of mercury

- Review evaporator design (not discussed in this report)

- Analyze plant samples for mercury speciation

\section{Review of Plant Data}

The SRS High Level Waste evaporator systems include the evaporator along with the feed and drop tanks. The $3 \mathrm{H}$ Evaporator differs from the $2 \mathrm{H}$ and $2 \mathrm{~F}$ Evaporators in several design features as shown in Table 1. First, the 3H Evaporator is larger with an operating volume of $\sim 10,000$ gallons versus 1750 gallons for the $2 \mathrm{~F}$ and $2 \mathrm{H}$ Evaporators. $^{2}$ Secondly, the system temperatures (feed tank, pot and drop tank) are $25{ }^{\circ} \mathrm{C}$ to $35{ }^{\circ} \mathrm{C}$ hotter in the $3 \mathrm{H}$ Evaporator compared to the other two evaporators.

\section{Table 1. SRS High Level Waste Evaporator Information}

\begin{tabular}{llll}
\hline & $2 \mathrm{~F}$ & $2 \mathrm{H}$ & $3 \mathrm{H}$ \\
& & & \\
Feed Tank & $26 \mathrm{~F}$ & $43 \mathrm{H}$ & $32 \mathrm{H}$ \\
Drop Tank & $46 \mathrm{~F}$ & $38 \mathrm{H}$ & $30 \mathrm{H}^{*}$ \\
Operating Volume (gal) & 1850 & 1850 & 9760 \\
Operating Temperature & $135^{\circ} \mathrm{C}$ & $135^{\circ} \mathrm{C}$ & $160^{\circ} \mathrm{C}$ \\
Feed Tank Temperature & $30^{\circ} \mathrm{C}$ & $30^{\circ} \mathrm{C}$ & $60^{\circ} \mathrm{C}$ \\
Drop Tank Temperature & $45^{\circ} \mathrm{C}$ & $45^{\circ} \mathrm{C}$ & $80^{\circ} \mathrm{C}$ \\
& & &
\end{tabular}

*Currently, Tank $37 \mathrm{H}$ is the drop tank. 
As previously mentioned, mercuric species are known to be reduced to elemental mercury during the evaporation of High Level Waste supernate and is subsequently volatized into the overheads collection system. Figure 2 shows the effect of temperature on the vapor pressure of elemental mercury. ${ }^{3}$ As observed, the vapor pressure increases by approximately one order of magnitude if the evaporator temperature is raised from $100{ }^{\circ} \mathrm{C}$ to $160{ }^{\circ} \mathrm{C}$. The increased vapor pressure should manifest as an increase in the amount of liquid, elemental mercury collected in the overheads system for a given feed mercury concentration.

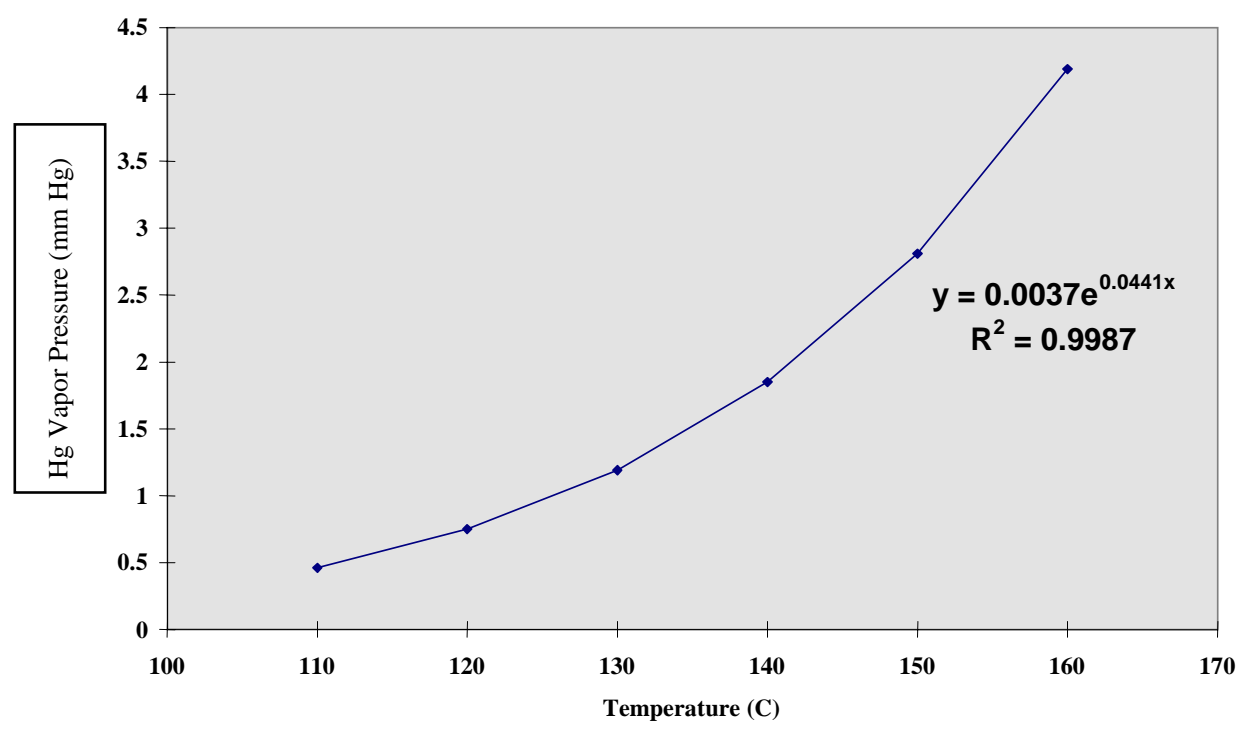

Figure 2. Mercury Vapor Pressure as a Function of Temperature

Table 2 contains a listing of the relevant plant operational data for the 3H Evaporator from August 2001 until the end of January 2002. The operational data includes the volume of condensate water generated for the dated 24-hr period, the amount of metallic mercury drained from the mercury collection tank, the evaporator pot temperatures and the Vent line temperature. JMP ${ }^{\circledR}$ software $^{4}$ was used to examine the amount of mercury produced (i.e., drained from the collection tank) against each of the other operational parameters. In particular, Figure 3 shows the plot of the evaporator pot temperature and the volume of mercury recovered from the overhead's system. The JMP $®$ model did not show a correlation between the amount of mercury recovered versus the pot temperature. The model has a correlation coefficient $\left(\mathrm{R}^{2}\right)$ of 0.04 even though the thermodynamics of metallic mercury should drive mercury into the overheads system. The effect of increased pot and system temperature does support higher mercury levels in the $3 \mathrm{H}$ overhead system. However, the amount produced cannot be solely attributed to the pot temperature. 
Wilmarth, et al.

WSRC-TR-2003-00238

Revision 1

Table 2. Historical Plant Data on $3 \mathrm{H}$ Operation

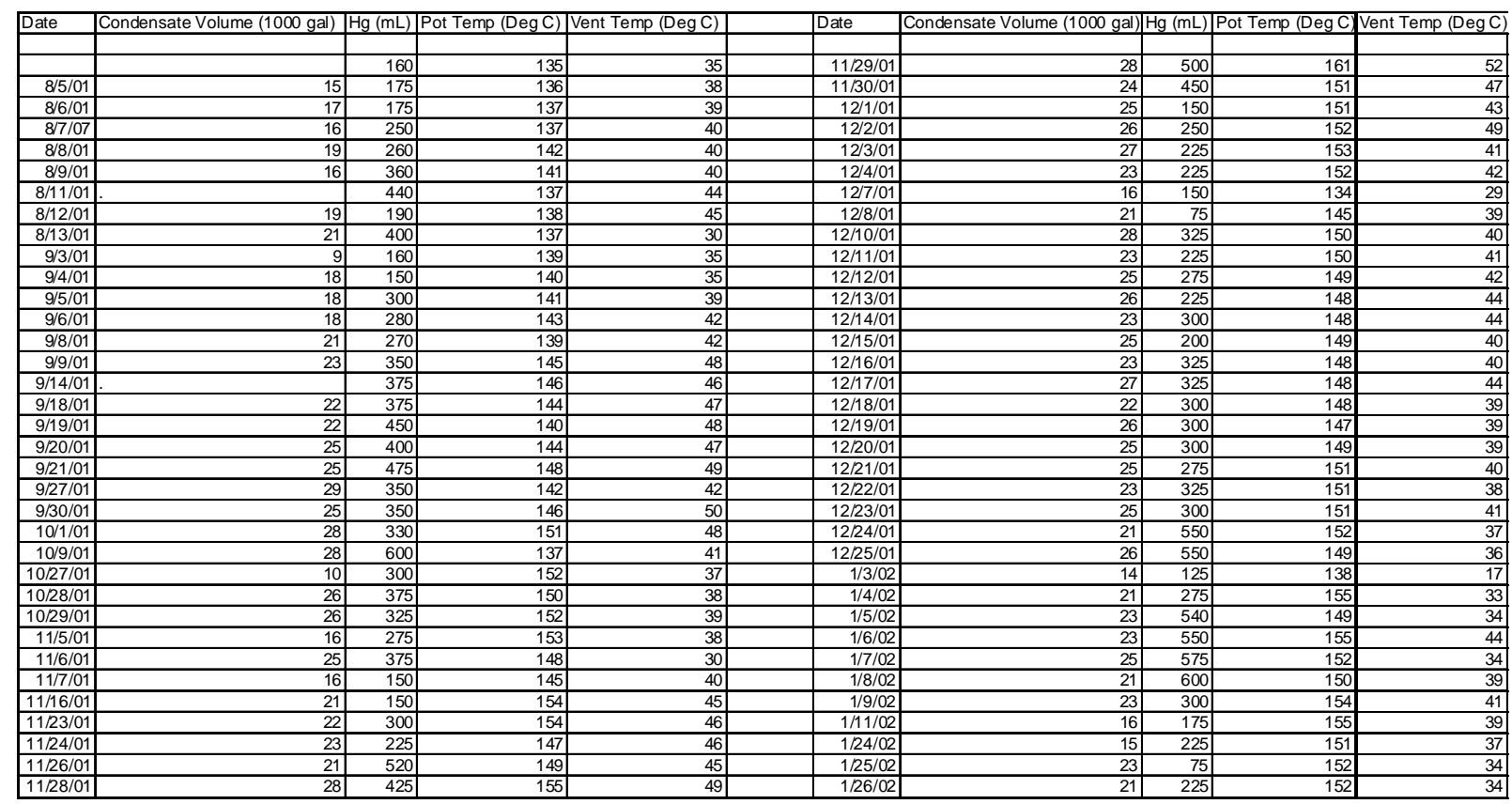

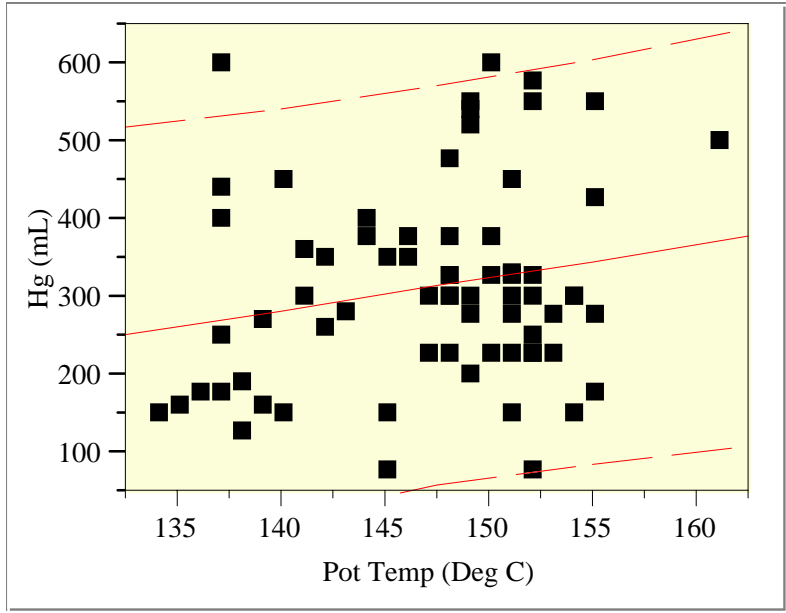

Figure 3. Plot of Operational Data for $3 \mathrm{H}$ Evaporator

Page 11 of 33 
The elevated mercury levels, associated with the $3 \mathrm{H}$ Evaporator compared to the $2 \mathrm{H}$ Evaporator, were originally thought to be related to the amount of High Level Waste sludge contained in the $3 \mathrm{H}$ system. Remembering that mercury partitions between the liquid supernatant phase and the insoluble sludge phase, a review of the Site's Waste Characterization Database (WG08) was performed. Figure 4 contains a representation of the $2 \mathrm{H}$ and $3 \mathrm{H}$ Evaporator systems. The sludge level in the $2 \mathrm{H}$ system is at a height of 58”; whereas, the sludge height is 32" in the 3H Evaporator feed tank. However, the mercury content of the sludges is quite different. The Waste Characterization Database indicates that the $2 \mathrm{H}$ sludge contains $\sim 1700 \mathrm{~kg}$ of mercury in the form of mercuric oxide, $\mathrm{HgO}$. The $3 \mathrm{H}$ sludge has a much higher mercury content and is estimated at $12,800 \mathrm{~kg}$ of HgO. Although this disparity in mercury content exists, solubility, reduction potential, and evaporator temperature drive the impact to mercury volatility. Therefore, the much larger mercury inventory in the 3H Evaporator system has little effect.

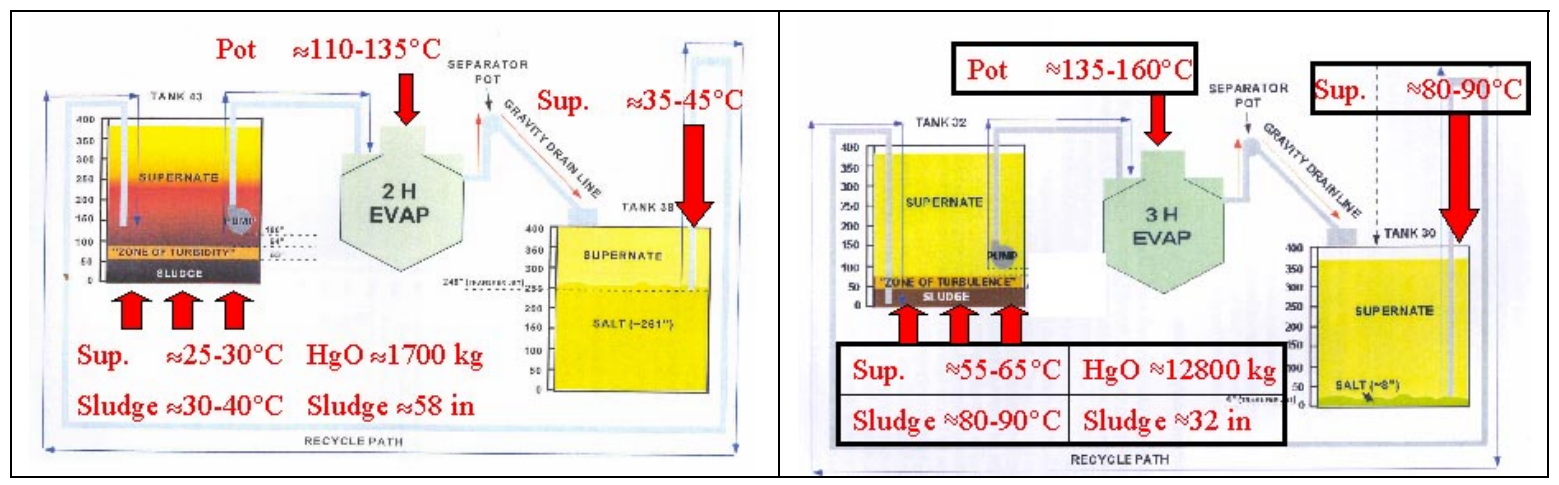

Figure 4. Comparison of $2 \mathrm{H}$ and $3 \mathrm{H}$ Evaporators

\section{Review of Published Literature on Mercury Chemistry}

The chemical understanding of the behavior of mercury species under the high $\mathrm{pH}$ conditions of the HLW tanks has been studied. However, several questions persist in light of elevated mercury levels in the $3 \mathrm{H}$ Evaporator system. The questions include:

- What is the solubility of mercuric ion as a function of temperature under high $\mathrm{pH}$ conditions?

- Is elemental mercury the only inorganic form of mercury that is volatized during HLW evaporation?

Three oxidation states of mercury can exist in solution concomitantly: the metal $\left(\mathrm{Hg}^{0}\right)$, mercurous ion $\left(\mathrm{Hg}^{+}\right.$or $\left.\mathrm{Hg}_{2}{ }^{2+}\right)$ or the mercuric ion $\left(\mathrm{Hg}^{2+}\right)$. As early as 1920, Fuseya ${ }^{5}$ studied the solubility of mercuric oxide in sodium hydroxide solutions for work related to $\mathrm{HgO}$ electrodes. Fuseya studied the Hg solubility in caustic solutions to $2 \mathrm{M} \mathrm{NaOH}$ and 
found mercury concentrations of $30.9 \mathrm{mM} \mathrm{HgO}$ or $6.2 \mathrm{~g} / \mathrm{L}$. However, the study lacked a filtration step to remove colloidal mercury species prior to acidification for analysis. Bibler $^{6}$ reviewed the solubility of selected metals $(\mathrm{Cd}, \mathrm{Pb}, \mathrm{Mn}$, and $\mathrm{Hg}$ ) for ground water application at the Savannah River Site. Figure 5 shows the distribution of hydrolysis products as a function of $\mathrm{pH}$. The mercury species at $\mathrm{pH} 14$ is governed by the $1,2(\mathrm{x}, \mathrm{y})$ species for the general formula of $\mathrm{Hg}_{x}(\mathrm{OH})_{y}{ }^{(2 x-y)^{+}}$, or $\mathrm{Hg}(\mathrm{OH})_{2}$. The plot indicates a mercury solubility of $2.4 \times 10^{-4} \mathrm{M}$ or $50.4 \mathrm{mg} / \mathrm{L}$ at $\mathrm{pH} 14$.

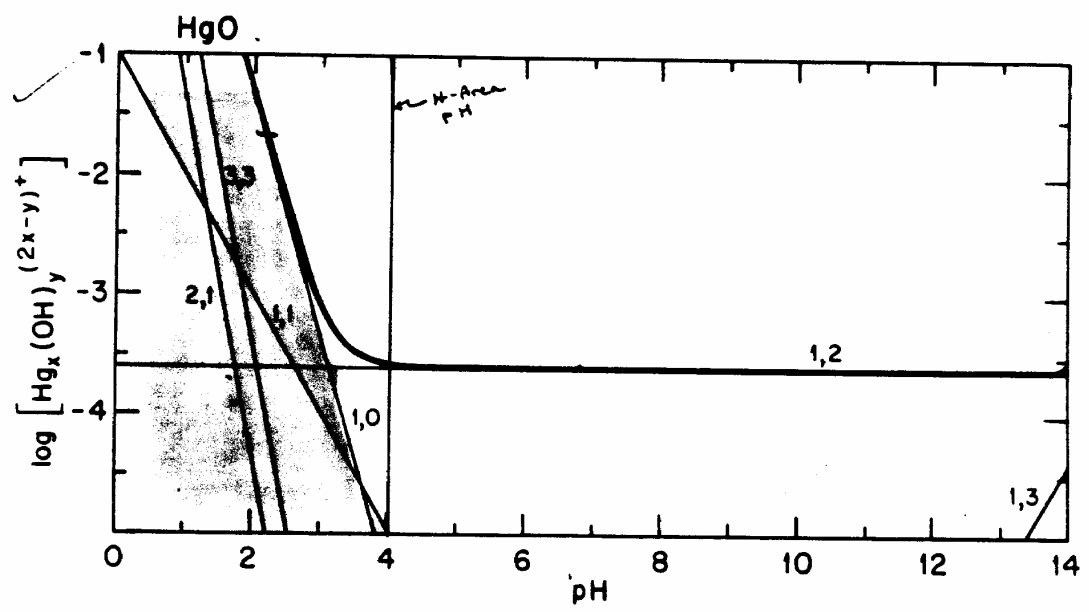

Figure 5. Distribution of Hydrolysis Products for Solutions Saturated with Hg $(\mathrm{OH})_{2}$

Zhou and Chen ${ }^{7}$ studied the effect of temperature on the solubility of mercury in solution of potassium hydroxide in the range of 1 to $7 \mathrm{M} \mathrm{KOH}$ and 25 to $55^{\circ} \mathrm{C}$. Figure 6 shows a plot of this data taken from their report. A maximum in the mercury concentration is observed at each temperature in the $\mathrm{KOH}$ concentration range of $1.5-2 \mathrm{M}$. The ordinate in the plot has units of mole/L multiplied by $10^{4}$; therefore, a value of 4 equates to a mercury concentration of $\sim 80 \mathrm{mg} / \mathrm{L}$. Temperature does appear to have a large effect on the solubility of mercuric ion. In $\mathrm{KOH}$, the mercuric ion solubility would be $62 \mathrm{mg} / \mathrm{L}$ at $25{ }^{\circ} \mathrm{C}$ at $4 \mathrm{M}$ hydroxide and $160 \mathrm{mg} / \mathrm{L}$ at $55^{\circ} \mathrm{C}$. This equates to a 2.6 fold increase in mercury concentration. If this data holds for sodium hydroxide solutions, the implication is that the mercury solubility in the 3H Evaporator Feed Tank (Tank 32H) would be higher in comparison to the $2 \mathrm{H}$ system.

In order to understand the solubility of mercury in sodium hydroxide-based systems, a commercially available software OLI chemical speciation model (OLI Software Systems, 1996) was used. The OLI software has a thermodynamic framework that predicts complex aqueous-based chemistry in equilibrium with optional vapor, nonaqueous liquid, and solid phases. The aqueous model is predictive over the general range of 0 to $300{ }^{\circ} \mathrm{C}$, 0 to 1500 bar and 0 to 30 (molal) ionic strength. The OLI databank is extensive, 


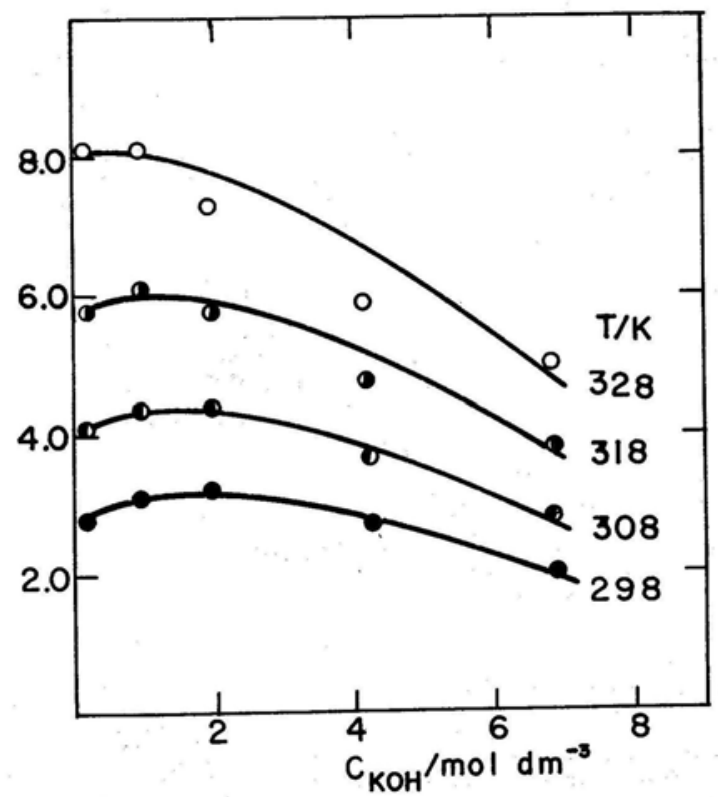

Figure 6. Mercury Concentration versus KOH Concentration

Ordinate has units of mole/ $\mathrm{L} * 10^{4}$

containing physical constants for over 3000 inorganic and organic species. The predictive framework is based on:

- the Revised Helgeson Equation of State for predicting the standard state thermodynamic properties of all species, including organics, in water;

- the Bromley-Zemaitis framework for the prediction of excess thermodynamic properties;

- the Pitzer and Setschenow formulation for the prediction of the excess thermodynamic properties calculation of molecular species in water; and

- the Enhanced SRK Equation of State for the prediction of vapor and nonaqueous, liquid-phase thermodynamic properties.

Figure 7 contains the output of the OLI modeling for mercury solubility in sodium and potassium hydroxide. The OLI database does not include nor completely agree with the work of Zhou and Chen and is a non-referenced private communication. However, the magnitude $\left(10^{-4} \mathrm{M}\right)$ of the mercury solubility is the same. There is a general increase in mercuric ion concentration with both increased hydroxide concentration and increased temperature.

In summary, the mercury solubility under highly alkaline conditions is fairly well known. The effect of temperature on the mercury solubility is classical, i.e.; increased temperature results in increased solubility. The higher temperature of the $3 \mathrm{H}$ Evaporator 
system should result in higher mercuric ion concentrations in the feed tank and enhance the potential for volatility when processed through the evaporator.

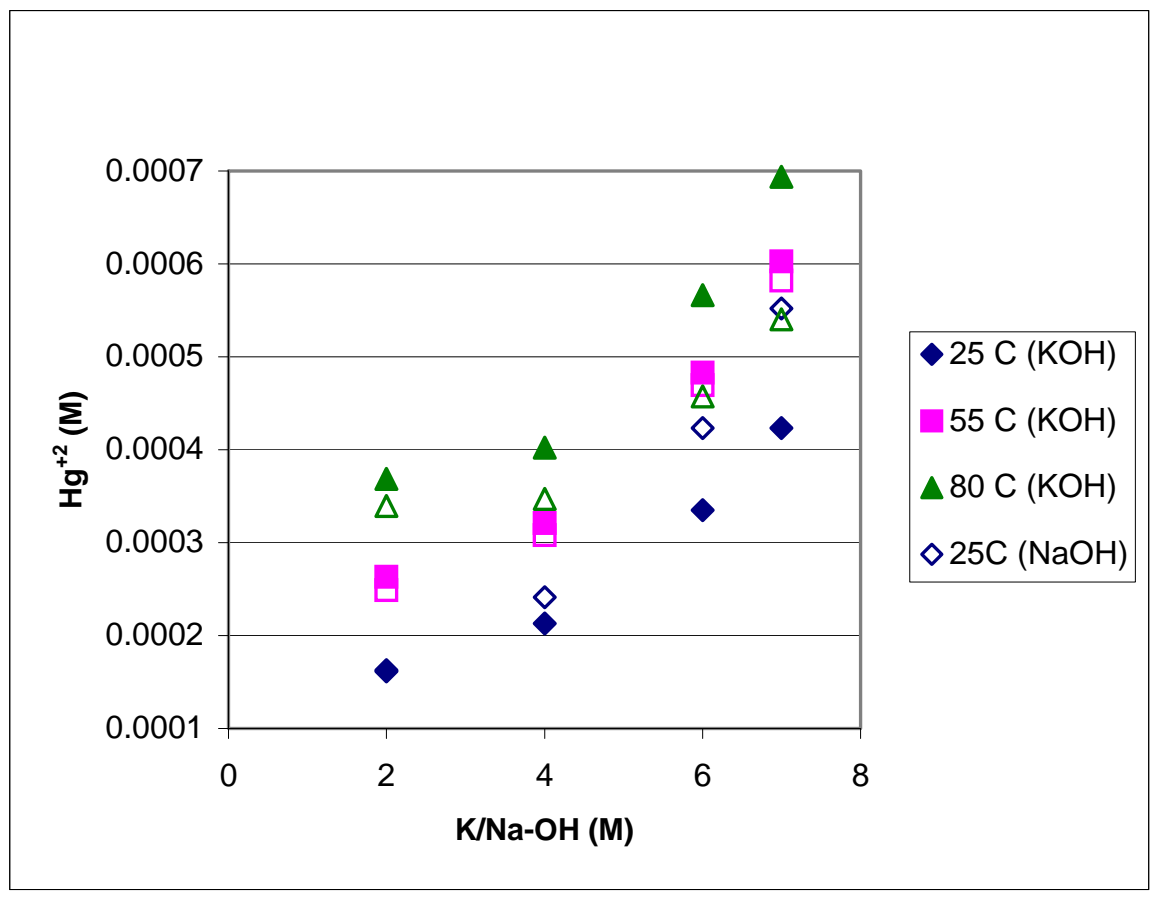

Figure 7. OLI Predicted Solubility as a Function of Caustic Concentration and Temperature

The second question regarding mercury chemistry is whether elemental mercury is the only inorganic species that volatilizes during the evaporation of HLW supernate. As previously mentioned, the chemistry of mercury is complicated by the co-existence of three oxidation states and the interrelation of these oxidation states via the disproportionation reaction shown below:

$$
\mathrm{Hg}_{2}{ }^{2+} \leftrightarrow \mathrm{Hg}^{\mathrm{o}}+\mathrm{Hg}^{2+}
$$

Bibler $^{8}$ has studied the formation of elemental mercury from evaporation of aqueous systems in support of the Effluent Treatment Facility. The tests examined reducing agents for the ETF process and the effects of mercury transport to condensate water. Table 3 contains a scanned copy of a table from the referenced report. For comparison purposes, a blank containing $1 \mathrm{mg}$ of mercuric $\left(\mathrm{Hg}^{2+}\right)$ ion was boiled and the volume reduced by a factor of 10 with very little mercury observed in the condensate phase 
(3.15E-3 mg). Conversely, with added reducing agent like bisulfite or stannous ion, a large fraction of the mercury was detected in the condensate.

Table 3. Reducing Agent Effect on Mercury Volatility

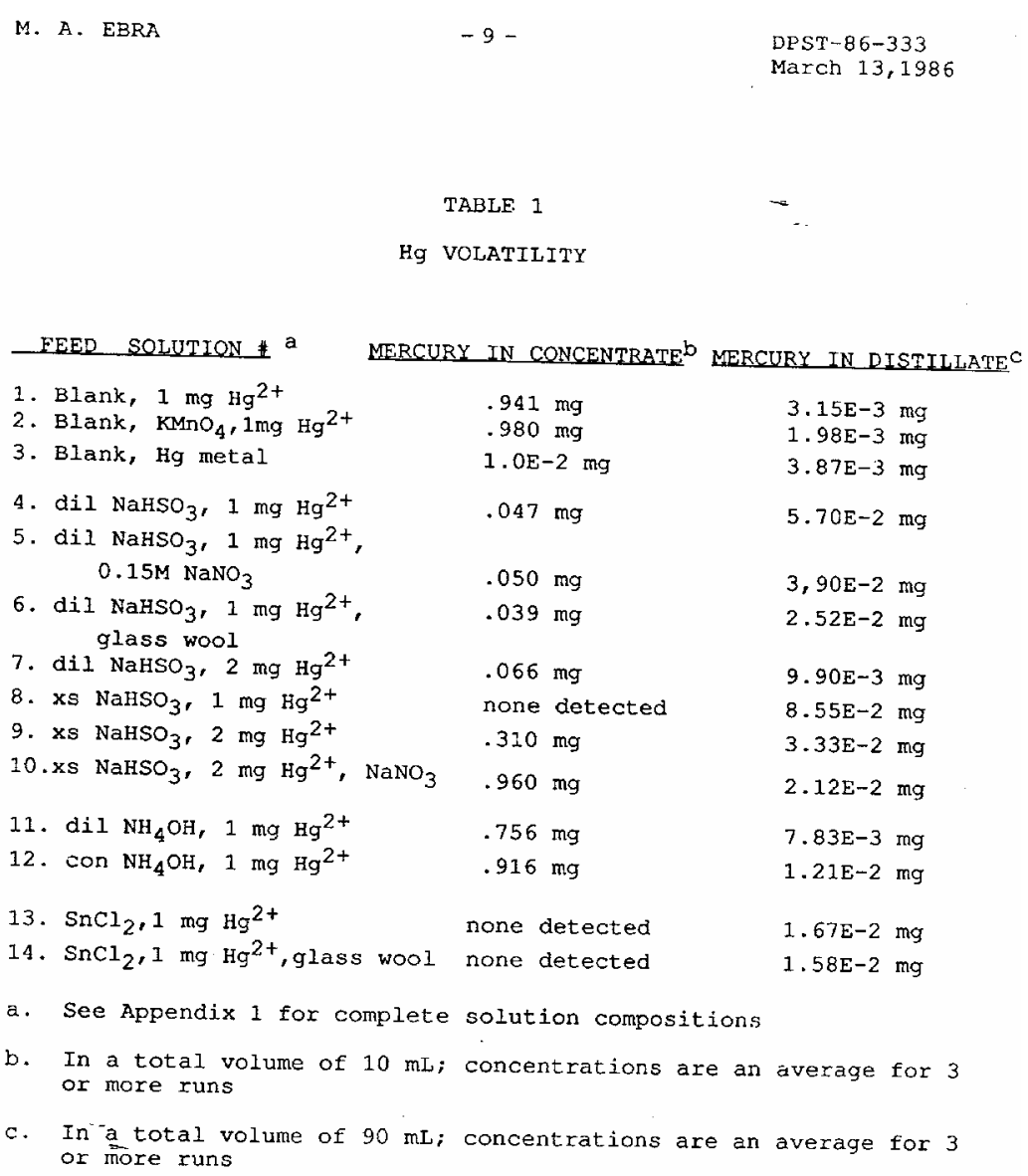

Although these tests supported ETF operation, their applicability to evaporator operation still holds. The chemical species tested do not have application to the evaporator. However, the evaporator systems do include other reducing agents in bountiful concentration like nitrite. The electrochemical potential for the mercury reduction by bisulfite and nitrite are shown below:

$$
\begin{array}{ll}
\mathrm{H}_{2} \mathrm{SO}_{3}+\mathrm{H}_{2} \mathrm{O}+\mathrm{Hg}^{2+}<-->\mathrm{Hg}+\mathrm{SO}_{4}{ }^{2-}+4 \mathrm{H}^{+} & \Delta \mathrm{eV}=1.3 \\
\mathrm{NO}_{2}{ }^{-}+2 \mathrm{OH}^{-}+\mathrm{Hg}^{2+}<-->\mathrm{NO}_{3}{ }^{-}+\mathrm{H}_{2} \mathrm{O}+\mathrm{Hg} & \Delta \mathrm{eV}=1.68
\end{array}
$$


The thermodynamic entropy or Gibb's Free Energy can be calculated from the formula $\Delta \mathrm{G}=\mathrm{-ZF} \Delta \mathrm{eV}$, where $\mathrm{F}=96,484 \mathrm{C} / \mathrm{mole}$ and $1 \mathrm{eV}=23.08 \mathrm{Cal} / \mathrm{mol}$. This gives rise to favorable chemical reactions with free energies of -125 and $-162 \mathrm{~kJ} / \mathrm{mol}$ for bisulfite and nitrite, respectively.

The OLI-Environmental Simulation Program (ESP) was used to simulate evaporation for steady state conditions. Figure 8 shows the results of this thermodynamic modeling. As observed, the mole fraction of elemental mercury found in the overhead condensate increases with increasing evaporator pot temperature (i.e., boiling point of solution). Essentially all of the mercury partitions to the overheads above $175^{\circ} \mathrm{C}$. The higher temperatures of the $3 \mathrm{H}$ Evaporator leads to a higher fraction of the mercury in the HLW supernate being found in the overhead mercury collection tank.

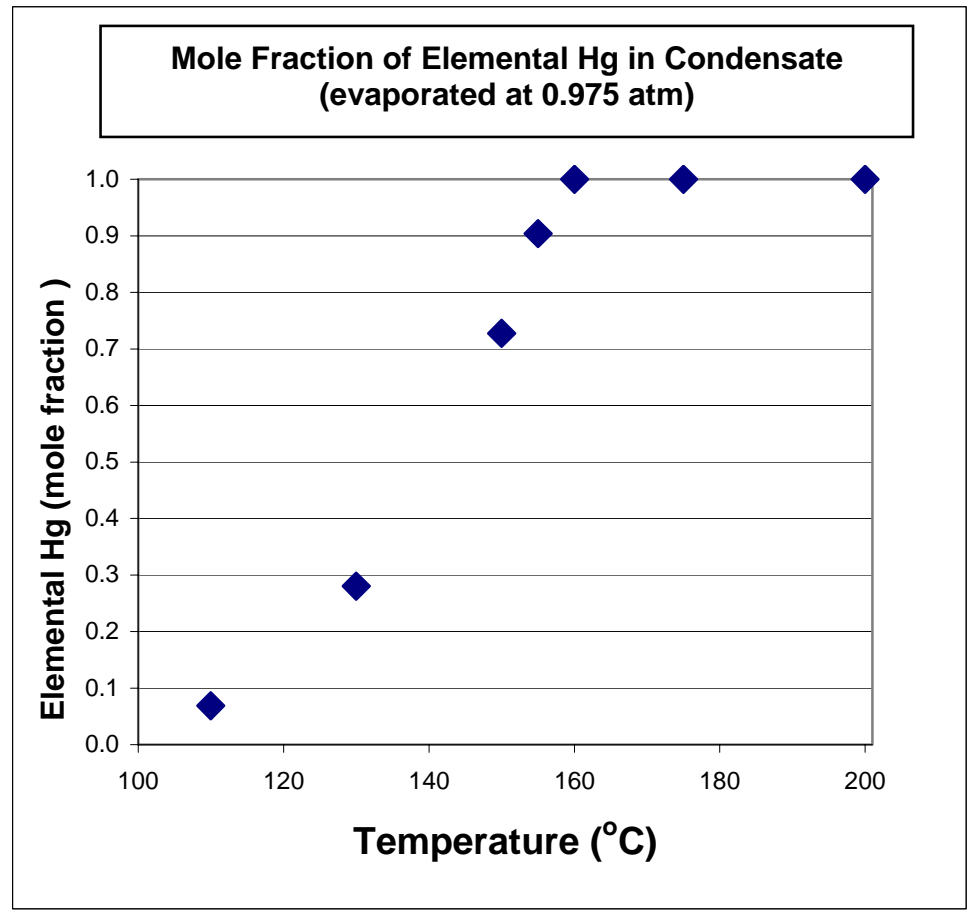

Figure 8. Mole Fraction of Elemental Hg in Condensate

\section{Analysis of Plant Samples for Mercury Speciation}

As part of the process to examine potential sources for the elevated mercury concentrations at the $3 \mathrm{H}$ Evaporator, one avenue that was explored was mercury speciation. Organomercury compounds traditionally have high vapor pressures. For example, dimethylmercury has a vapor pressure of $50 \mathrm{~mm}$ of $\mathrm{Hg}$ compared to $15 \mathrm{~mm} \mathrm{Hg}$ for water at $25^{\circ} \mathrm{C}$. Therefore, contact was made with personnel at Frontier Geosciences, Inc. in Seattle Washington. Frontier Geosciences is a recognized world leader in 
developing specific methods for analyzing trace inorganic metal ions and their speciation in complex chemical systems. They are considered an expert in the chemistry of organomercury species.

The first liquid samples pulled were from the 3H overhead condensate tank on April 29, 2002. The results ${ }^{9}$ indicated that a dimethylmercury concentration of $0.479 \mathrm{mg} / \mathrm{L}$; well above the detection limit for Frontier's laboratory. Subsequent to that analysis a set of samples taken from the $3 \mathrm{H}, 2 \mathrm{H}$ and $2 \mathrm{~F}$ overhead tanks was analyzed by the Analytical Development Section in SRTC and showed values of 0.13, 0.026, and $<0.002 \mathrm{mg} / \mathrm{L}$, respectively. This dual laboratory confirmation clearly indicated that dimethylmercury was present and at levels that could potentially require Industrial Hygiene review for exposure control. Rosencrance and Wilmarth, ${ }^{10}$ also, attempted to provide approaches for calculating the airborne concentrations of dimethylmercury.

A SRS path forward was developed to examine each of the evaporator liquid condensate systems along with the Effluent Treatment Plant. ${ }^{11}$ This path forward described the sample strategy to effectively utilize the existing resources at SRS and at Frontier Geosciences. Samples, both liquid and vapor, were collected and analyzed for monomethylmercury, dimethylmercury and total mercury from numerous locations at the 2F, $2 \mathrm{H}$ and $3 \mathrm{H}$ Evaporators along with the transfer line to the Effluent Treatment Facility and internal to the facility. Figure 9 shows a summary of the samples from each facility for samples through March of 2003. Detailed sample information is included in Appendix 1.

The 3H Evaporator has received the most sampling for dimethylmercury. There have been 16 liquid samples and 30 vapor samples. Of the liquid samples, all have tested positive for the presence of dimethylmercury. The dimethylmercury concentrations have ranged from 94 to 14,000 $\mu \mathrm{g} / \mathrm{L}$. For comparison purposes, selected information on dimethylmercury is shown in Table 4 . Of the 30 vapor samples, 25 samples have shown dimethylmercury as being present. Five of these measurements were above the Threshold Limit Value (TLV) and three were above the Ceiling value. The concentrations have ranged from $<0.02$ to $>175 \mu \mathrm{g} / \mathrm{m}^{3}$.

As of early March 2003, 10 liquid and 10 vapor samples from the 2H Evaporator were taken and analyzed. All of the liquid samples have been positive for dimethylmercury but the maximum concentration $(2200 \mu \mathrm{g} / \mathrm{L})$ is not that much below the $3 \mathrm{H}$ system. All of the vapor samples have shown the presence of dimethylmercury but the maximum concentration measured at $>89 \mu \mathrm{g} / \mathrm{m}^{3}$. 
Figure 9. Summary of DMHg in Vapor and Liquid Samples

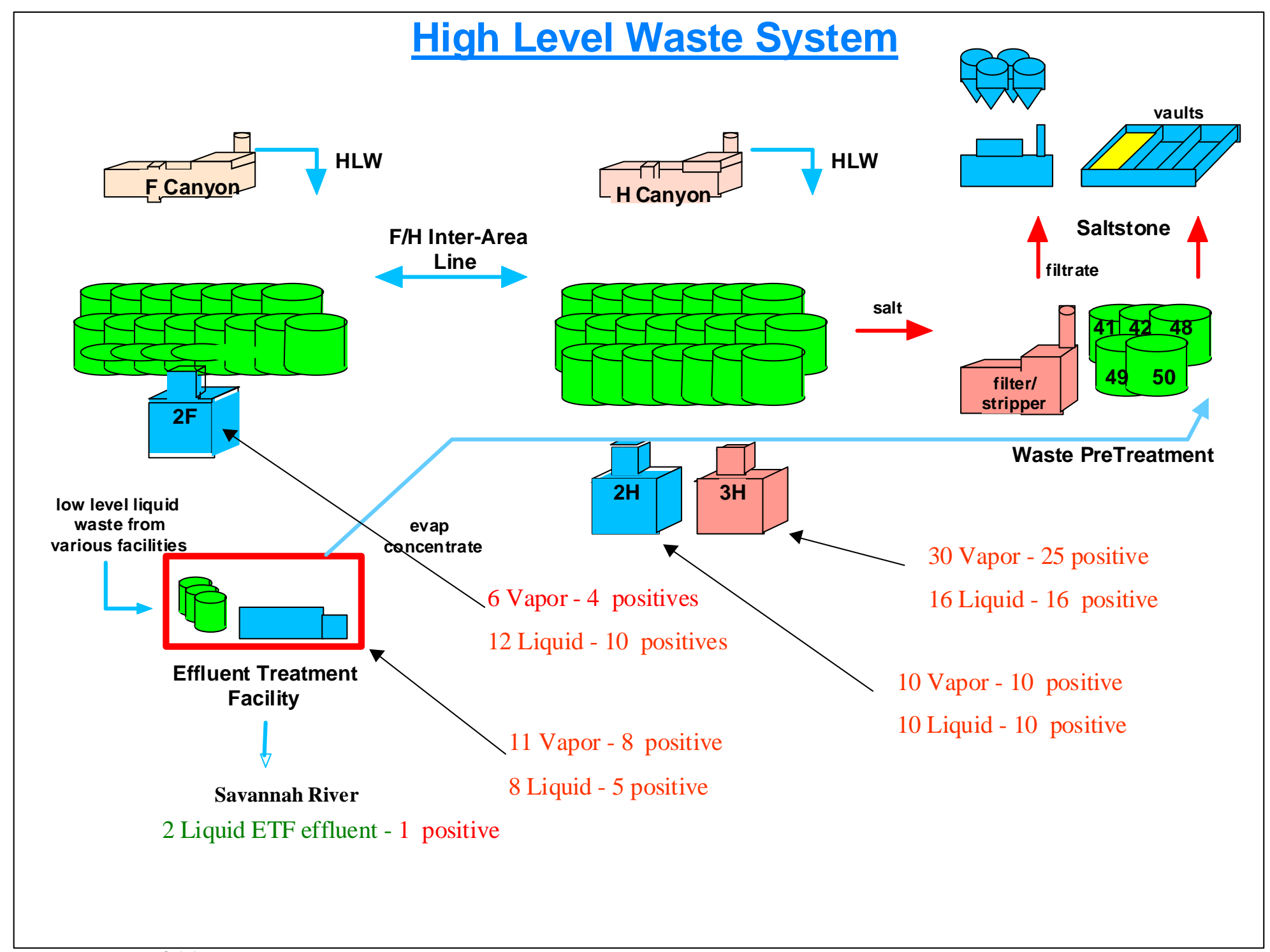




\section{Table 4. Dimethylmercury Information}

Formula: $\left(\mathrm{CH}_{3}\right)_{2} \mathrm{Hg}$ (molecular weight: $\left.230.7 \mathrm{~g} / \mathrm{mole}\right)$

Appearance and odor: Colorless liquid with a weak, sweetish odor.

Boiling point: $95^{\circ} \mathrm{C}$ Vapor density: 7.9 (air = 1)

Vapor Pressure @ $20{ }^{\circ} \mathrm{C}=50 \mathrm{~mm} \mathrm{Hg}$ (water=17.3 mm Hg)

Distribution coefficient ([air]/[liquid] $)=0.31$ at $25^{\circ} \mathrm{C}$

Toxicology: Causes dysfunction of central nervous system and irritates membranes and skin

Site and Regulatory Limits:

Air: OSHA TLV $(8 \mathrm{~h})=10 \mu \mathrm{g} / \mathrm{m}^{3}$, ACGIH STEL $=30 \mu \mathrm{g} / \mathrm{m}^{3}$, OSHA PEL-Ceiling $=40$ $\mu \mathrm{g} / \mathrm{m}^{3}$

Liquid: Site IH Guide $=100 \mu \mathrm{g} / \mathrm{L}$, Fed Drinking Water Std $=2 \mu \mathrm{g} / \mathrm{L}$

Discharge to Waters of State: No DMHg specific limit, total Hg limit $=2.3 \mu \mathrm{g} / \mathrm{L}$

The 2F Evaporator system processes less mercury compared to the H-area systems as previously described in the Introduction to this report. Therefore, the measurements taken from the $2 \mathrm{~F}$ system show much lower concentrations of dimethylmercury. Ten out of 12 liquid samples have tested positive with a maximum concentration of $2.6 \mu \mathrm{g} / \mathrm{L}$ or approximately 5 times lower than the lowest $\mathrm{H}$-area liquid samples $(14.1 \mu \mathrm{g} / \mathrm{L})$. Four of six vapor samples have indicated the presence of dimethylmercury with a concentration that ranged from 0.012 to $0.734 \mu \mathrm{g} / \mathrm{m} 3$.

Because of the concentrations found in the evaporator condensates, samples were taken at the midpoints of the piping leading from the evaporators to the Effluent Treatment Facility (ETF). The ETF processes the condensate along with other wastes through evaporation, filtration, ion exchange and reverse osmosis. The samples (both liquid and vapor) were taken from the F- and H-Lift Stations along with the waste collection tank and the waste concentrate tank. Five of the 8 liquid samples were positive for the presence of dimethylmercury with a maximum concentration of $96.7 \mu \mathrm{g} / \mathrm{L}$ at the $\mathrm{H}$-Lift Station. Vapor measurements at the H-Lift Station ventilation exhaust and the carbon column sumps showed very high dimethylmercury levels estimated at $180 \mu \mathrm{g} / \mathrm{m}^{3}$.

A second sampling was associated with a caustic wash of an ion exchange column and subsequent discharge to a sump located at ETF. The ion exchange column is loaded with Duolite GT-73 cation exchange resin that has a high affinity for removing mercury from water in the $\mathrm{pH}$ range of 3 to 13. The caustic wash eliminates a bio-fouling that increases the pressure drop across the column. Samples from the vapor space in the sump at deck level were very high $>89 \mu \mathrm{g} / \mathrm{L}$. The cause of this dimethylmercury detection is still under investigation.

Page 20 of 33 
Vapor samples were taken for six waste tanks during May, 2003. Preliminary results from this sampling evolution ${ }^{12}$ show high levels of total mercury for all of the tanks and high levels of dimethylmercury for Tanks 38, 41, and 43. Additional samples and evaluations are planned to confirm and better understand the preliminary results.

Since Revision 0 of this report, a significant amount of sampling and analysis for mercury and organomercury species has been conducted. Sampling campaigns have examined the vapor space of several High Level Waste tanks. Additional samples have examined the 2F Evaporator, ETF locations and the process sewer manholes leading to ETF. It is the intention of the authors to incorporate these data and the remainder of FY04 sampling results in a subsequent revision. Table 5 contains a short listing of the latest sampling data.

\section{Dimethylmercury Formation and Degradation Tests}

Frontier Geosciences ${ }^{13}$ was contracted to perform initial testing into the possible formation of dimethylmercury. A simulated salt solution composition was provided to Frontier. Four organic components were $\operatorname{chosen}^{14}$ as candidate methylating agents. The four organic compounds were digested ion exchange resin, Dow Corning H-10 antifoam, trimethylsilanol and sodium acetate. Reactions were carried out at the solution boiling point and at $50{ }^{\circ} \mathrm{C}$ in the reaction vessel shown in Figure 10 .

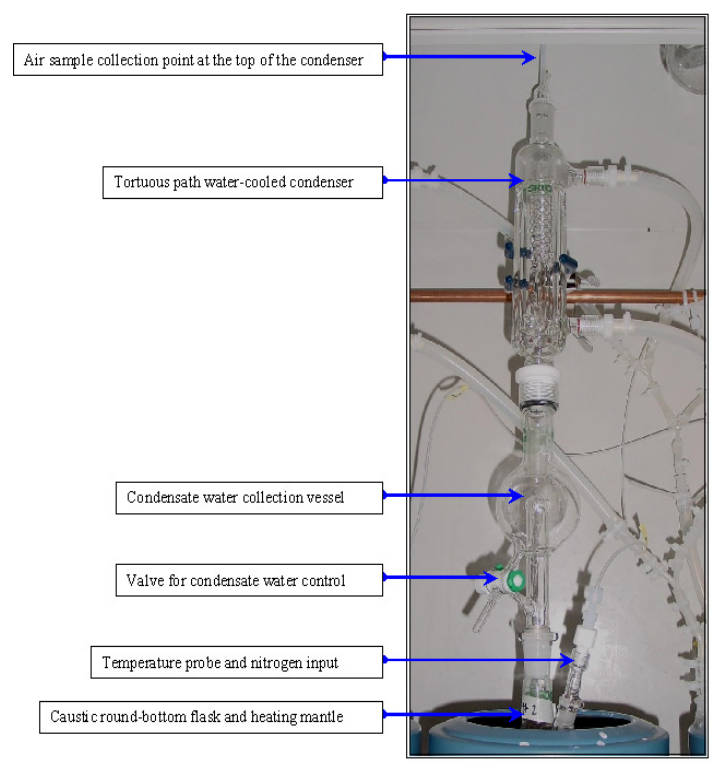

Figure 10. Dimethylmercury Reaction Vessel 
Table 5. Summary of Sampling Data post Revision 0

\author{
Waste Tanks (vapor sampling) \\ - 40 total samples taken (from 28 different waste tanks) - all were positive for DMHg \\ Dimethylmercury Results \\ - 26 samples (from 21 tanks) were $<1 \mathrm{ug} / \mathrm{m}^{3}$ \\ - 3 samples (from 2 tanks) were $>1 \mathrm{ug} / \mathrm{m}^{3}$ but $<10 \mathrm{ug} / \mathrm{m}^{3}$ (OSHA $8 \mathrm{hr}$ TWA TLV) \\ - 7 samples (from 4 tanks) were $>10 \mathrm{ug} / \mathrm{m}^{3}$ but $<40 \mathrm{ug} / \mathrm{m}^{3}$ (OSHA ceiling limit) \\ - 4 samples (from 2 tanks) were $>40 \mathrm{ug} / \mathrm{m}^{3}$
}

Total Hg Results

- 10 samples (from 9 tanks) were $<25 \mathrm{ug} / \mathrm{m}^{3}$ (OSHA $8 \mathrm{hr}$ TWA TLV for elemental Hg)

- 9 samples (from 8 tanks) were $>25 \mathrm{ug} / \mathrm{m}^{3}$ but $<125 \mathrm{ug} / \mathrm{m}^{3}$ (ACGIH ceiling for elemental $\mathrm{Hg}$ )

- 21 samples (from 14 tanks) were $>125 \mathrm{ug} / \mathrm{m}^{3}$

Manholes (3) vapor sampling

DMHg Results

- 1 sample (from 1 manhole) was $<1 \mathrm{ug} / \mathrm{m}^{3}$

- 2 samples (from 2 manholes) were $>40 \mathrm{ug} / \mathrm{m}^{3}$ (OSHA ceiling limit)

Total Hg Results

- 1 sample (from 1 manhole) was $<25 \mathrm{ug} / \mathrm{m}^{3}$ (OSHA $8 \mathrm{hr}$ TWA TLV for elemental Hg)

- 1 sample (from 1 manhole) was $>125 \mathrm{ug} / \mathrm{m}^{3}$ (ACGIH ceiling for elemental Hg)

ETP Samples

- 7 vapor samples from 5 different locations

DMHg Results

- All 7 samples were $<1 \mathrm{ug} / \mathrm{m}^{3}$

Total Hg Results

- 6 samples were $<25 \mathrm{ug} / \mathrm{m}^{3}$ (OSHA $8 \mathrm{hr}$ TWA TLV for elemental Hg)

- 1 sample was $>25 \mathrm{ug} / \mathrm{m}^{3}$ but $<125 \mathrm{ug} / \mathrm{m}^{3}$ (ACGIH ceiling for elemental Hg)

2F Evaporator Samples

Vapor DMHg Results

- 4 samples from different locations

- 3 samples were $<1 \mathrm{ug} / \mathrm{m}^{3}$

- 1 sample was $>1 \mathrm{ug} / \mathrm{m}^{3}$ but $<10 \mathrm{ug} / \mathrm{m}^{3}$ (OSHA 8 hr TWA TLV)

2 liquid samples - both were positive for DMHg

2H Evaporator Samples

Vapor DMHg Results

- 1 sample taken - sample was $>40 \mathrm{ug} / \mathrm{m}^{3}$ (OSHA ceiling limit)

Total Hg Results

- 1 sample taken - sample was > $125 \mathrm{ug} / \mathrm{m}^{3}$ (ACGIH ceiling for elemental Hg)

2 liquid samples - both were positive for DMHg

H Catch Tank Samples

Vapor DMHg Result was $<1 \mathrm{ug} / \mathrm{m}^{3}$

Total Hg result was $>25 \mathrm{ug} / \mathrm{m}^{3}$ (OSHA 8 hr TWA TLV for elemental Hg), but $<125 \mathrm{ug} / \mathrm{m}^{3}$ (ACGIH ceiling for elemental $\mathrm{Hg}$ )

1 liquid sample - positive for DMHg ( $<1 \mathrm{ug} / \mathrm{L})$

TWA - Time Weighted Average and TLV - Threshhold Limit Value 
In this first round of testing, ${ }^{15,16}$ mercury was readily converted to elemental form in boiling solution and dimethylmercury was formed with each of the organic species tested under boiling conditions. The highest yield of dimethylmercury formation was $0.38 \%$ with high $\mathrm{Hg}$ and antifoam. In contrast, blanks showed no dimethylmercury formation indicating that the formation results were valid. Tests were conducted with single components, binary mixtures and all four components in an attempt to determine if one single component was responsible for the methylation. Results were not conclusive; however, Frontier personnel suggested that antifoam was the most effective methylating agent.

Dimethylmercury was not formed under lower temperature $\left(\sim 50^{\circ} \mathrm{C}\right)$ within 4 hrs. Kinetic testing indicated higher yields near experiment end indicating that measured yields were not equilibrium yields. Additionally, the formation of dimethylmercury was strongly depended on starting $\mathrm{Hg}$ concentration with a 4x increase in starting $\mathrm{Hg}$ concentration leading to 620-fold increase in dimethylmercury formation. Similarly, increasing the organic concentration by 10 -fold led to a 68-fold increase in dimethylmercury formation.

Subsequent to the initial round of testing, SRS requested Frontier to perform two additional phases ${ }^{17}$ of testing. In the next phase (the second overall), the decomposition of dimethylmercury was studied in simulated waste matrices to examine the duration that the chemical would exist. These matrices were selected to reproduce conditions within the High Level Waste system. The matrices were $\mathrm{pH} 2$ for the Effluent Treatment Facility, pH 10 Evaporator condensate, and 9 M sodium supernate for the Evaporator and waste tanks. Three temperatures were examined $\left(40,65\right.$ and $\left.80{ }^{\circ} \mathrm{C}\right)$ over duration of 600 $\mathrm{h}$. In the third and final phase of testing, these matrices were used to examine the formation of dimethylmercury over similar conditions of temperature and time.

Table 6 shows the results of the decomposition testing. Included are the calculated half lives, $\mathrm{t}_{1 / 2}$, for dimethylmercury in the solution matrices at the three temperatures. For the pH 2 matrix, Frontier initially used hydrochloric acid to acidify the water and repeated the tests using nitric acid to better align the chemistry to that at the Effluent Treatment Facility. The data, in general, indicate that dimethylmercury is fairly stable. For example, at ETF the expectation was that the acidification step early in the process would decompose the dimethylmercury and subsequent process would not pose exposure potential. However, with a half life of $\sim 12$ hours at $40{ }^{\circ} \mathrm{C}$, the acidification step and subsequent neutralization step does not allow sufficient time for the dimethylmercury to decompose. Dimethylmercury is most stable in the $\mathrm{pH} 10$ chemistry of the evaporator overhead tanks. The half life in that chemistry is over 1 year.

In the last phase of testing, Frontier examined the formation of dimethylmercury. For each set of conditions, the amount of $\left(\mathrm{CH}_{3}\right)_{2} \mathrm{Hg}$ production increased approximately linearly with time, and exponentially with increasing temperature. At any given temperature and time, the samples containing a mixture of methyl donors (the most potent of which is the antifoam agent polymethyldisiloxane) plus acetate generated 
approximately two orders of magnitude more $\left(\mathrm{CH}_{3}\right)_{2} \mathrm{Hg}$ than did the acetate alone. By the end of the experiment, a maximum of $2 \%$ of the total $\mathrm{Hg}$ initially present $\left(10 \mathrm{mg} \mathrm{L}^{-1}\right)$ had been converted to $\left(\mathrm{CH}_{3}\right)_{2} \mathrm{Hg}$ with the mixed organics incubated at $80^{\circ} \mathrm{C}$.

Another aspect of these formation tests was whether sludge could catalyze the formation of dimethylmercury. Testing introduced sludge to the supernate and found that neither of the synthetic sludges was seen to have an effect of methylation in any of the experiments. This indicates that the presence of these solids was not catalytic with respect to methylation or demethylation of $\mathrm{Hg}$. By the end of the experiment, complete analysis showed that much of the $\mathrm{Hg}$ not in the form of $\left(\mathrm{CH}_{3}\right)_{2} \mathrm{Hg}$ was present as monomethyl mercury $\left(\mathrm{CH}_{3} \mathrm{Hg}\right)$. This suggests that these alkaline waste solutions can rapidly methylate all of the $\mathrm{Hg}(\mathrm{II})$ present in solution to $\mathrm{CH}_{3} \mathrm{Hg}$, and then, more slowly over time, a second methyl group is added, forming $\left(\mathrm{CH}_{3}\right)_{2} \mathrm{Hg}$.

Table 6. Decomposition Data

\begin{tabular}{|c|c|c|c|}
\hline \multirow{2}{*}{ Matrix } & \multicolumn{3}{|c|}{ Calculated Decay Half-Life (hours) } \\
\cline { 2 - 4 } & $\mathbf{3 9}^{\mathbf{0}} \mathbf{C}$ & $\mathbf{6 5}{ }^{\mathbf{0}} \mathbf{C}$ & $\mathbf{8 3}{ }^{\mathbf{0}} \mathbf{C}$ \\
\hline \hline $7 \mathrm{M} \mathrm{NaOH}+1 \mathrm{M} \mathrm{NaNO}_{3}+1 \mathrm{M} \mathrm{NaNO}_{2}$ & 814 & 276 & 154 \\
\hline $\left.\mathrm{pH} \mathrm{10} \mathrm{(NaOH}+\mathrm{NaNO}_{3}+\mathrm{NaNO}_{2}\right)$ & 9,565 & 1,929 & 617 \\
\hline $\mathrm{pH} 2.0(\mathrm{HCl}+\mathrm{glycine})$ & 16.4 & 5.6 & 2.7 \\
\hline $\mathrm{pH} 2.0\left(\mathrm{HNO}_{3}\right)$ & 11.8 & 3.1 & 0.9 \\
\hline
\end{tabular}

\section{CURRENT PATH FORWARD}

The investigation into mercury related issues involving High Level Waste operations has shown the thermodynamic behavior of mercury in the elemental state and as mercuric ion in solution. Additionally, the investigation has revealed that chemical reactions between mercury and organic constituents produce alkyl mercury species. The report is an attempt to centralize information and provide a reference to field measurements. Concomitant with the publication of this report are a series of additional activities. To provide an appreciation of the breadth of these activities, a subset is listed below:

- Additional liquid and vapor sampling from the three evaporator systems and ETF

- Validation sampling to ensure ventilation changes in the $3 \mathrm{H}$ system are effective

- Design, construction and installation of ventilation changes to the 2H Evaporator system, F and $\mathrm{H}$ Area Lift Stations, and possibly the 2F Evaporator system

- Additional vapor sampling of waste tank head spaces (including waste tanks independent of evaporator systems) to examine the potential for other release pathways 


\section{SUMMARY}

The chemistry and thermodynamics of mercury across the evaporation process for High Level Waste has been examined. Soluble mercuric and mercurous ions are readily reduced under the highly alkaline conditions of the waste to form elemental mercury. The mercury metal is volatilized during evaporation and condenses in the overheads system. The higher temperatures of the larger $3 \mathrm{H}$ Evaporator understandably results in higher mercury volumes collected. Additionally, the current $3 \mathrm{H}$ Evaporator feed tank contains a sludge that is very high in mercury content. The frequent recycles from the evaporator drop tank (due to limited supernate volume) cause the feed tank to be at an elevated temperature. This increases the mercury solubility and likely leads to increased leaching of mercury from the sludge.

Investigations into other aspects of mercury interactions with waste components have indicated the mercury reacts under elevated temperatures with a number of organic species to form dimethylmercury. Under evaporator conditions, this volatile species is partitioned to the overheads condensate. Liquid and vapor measurements of the overhead cell areas showed the presence of dimethylmercury. Subsequent laboratory tests also showed formation of dimethylmercury when waste simulant is spiked with mercury and organic components. Data from the research shows that dimethylmercury formation is controlled by the amount on mercury in solution; is limited by the low concentration of organic components in the waste; and is favored at elevated temperature regimes, e.g., evaporators, drop tanks and high heat waste tanks. Additionally, sludge has not shown a catalytic effect for the formation of dimethylmercury.

Initial waste tank vapor sampling has shown that dimethylmercury is present in the vapor space of several waste tanks. This sampling has also indicated that the presence of dimethylmercury is not limited to the evaporator systems since Tank 41 vapor samples were among those positive for dimethylmercury (Tank 41 is a salt tank that is not currently associated with the operation of any evaporator).

\section{ACKNOWLEDGEMENTS}

The authors wish to express their sincere appreciation to the following personnel

- Dan Barnes for OLI Modeling

- Tommy Edwards for Statistical Modeling and Analysis

- Nicholas Bloom and Eric Prestbo for their technical support, analysis of field samples and R\&D testing into dimethylmercury formation

- Dan Kaplan for providing the description of the OLI modeling program

- Rob Swingle for description of original mercury discussion 


\section{Appendix 1. Detailed Sample Information}

DMHg = dimethylmercury, $\mathrm{MMHg}=$ monomethylmercury, $\mathrm{TMHG}=$ total methylmercury, EDMHg = estimated dimethylmercury, and THg = total mercury, Fac. $=$ facility and Pres. = preservative

\section{H Evaporator Liquid Results}

\begin{tabular}{|c|c|c|c|c|c|c|c|c|}
\hline Sample Number & Location & Date & Fac. & Pres. & $\begin{array}{c}\text { DMHg } \\
\mu g / L\end{array}$ & $\begin{array}{c}\text { MMHG } \\
\mu \mathrm{g} / \mathrm{L}\end{array}$ & $\begin{array}{c}\text { TMHG } \\
\mu \mathrm{g} / \mathrm{L}\end{array}$ & $\begin{array}{l}\mathrm{THg} \\
\mu \mathrm{g} / \mathrm{L}\end{array}$ \\
\hline WSRC rep 1 & & $4 / 29 / 02$ & $3 \mathrm{H}$ & $\mathrm{HCL}$ & & 1118 & & 1831 \\
\hline WSRC rep 2 & & $4 / 29 / 02$ & $3 \mathrm{H}$ & $\mathrm{HCL}$ & & 1186 & & 1693 \\
\hline WSRC rep 3 & & $4 / 29 / 02$ & $3 \mathrm{H}$ & $\mathrm{HCL}$ & & 1137 & & 1472 \\
\hline WSRC rep 4 & & $4 / 29 / 02$ & $3 \mathrm{H}$ & NP & 405 & & & \\
\hline WSRC rep 5 & & $4 / 29 / 02$ & $3 \mathrm{H}$ & NP & 503 & & & \\
\hline WSRC rep 6 & & $4 / 29 / 02$ & $3 \mathrm{H}$ & NP & 530 & & & \\
\hline 300179673 & & $5 / 2 / 02$ & $3 \mathrm{H}$ & NP & 130 & & & \\
\hline Primary $\mathrm{OH}$ & Primary Overheads Sample Station & $11 / 6 / 02$ & $3 \mathrm{H}$ & $\mathrm{HCL}$ & & 2001.3 & 4896.1 & 7156.3 \\
\hline Alternate $\mathrm{OH} \# 1$ & Alternate Overheads Sample Point \#1 & $11 / 6 / 02$ & $3 \mathrm{H}$ & $\mathrm{HCL}$ & & 6427.6 & 10543.3 & 9116.3 \\
\hline Alternate $\mathrm{OH} \# 2$ & Alternate Overheads Sample Point \#2 & $11 / 6 / 02$ & $3 \mathrm{H}$ & $\mathrm{HCL}$ & & 7284.9 & 10247.8 & 7103.9 \\
\hline Primary $\mathrm{OH}$ & Primary Overheads Sample Station & $11 / 6 / 02$ & $3 \mathrm{H}$ & NP & 2894.8 & & & \\
\hline Alternate $\mathrm{OH} \# 1$ & Alternate Overheads Sample Point \#1 & $11 / 6 / 02$ & $3 \mathrm{H}$ & NP & 4115.7 & & & \\
\hline Alternate $\mathrm{OH} \# 2$ & Alternate Overheads Sample Point \#2 & $11 / 6 / 02$ & $3 \mathrm{H}$ & NP & 2962.9 & & & \\
\hline $\mathrm{MeOH}$ & Alternate Overheads Sample Point \#1 & $11 / 6 / 02$ & $3 \mathrm{H}$ & $\mathrm{MeOH}$ & 3326 & & & \\
\hline 300188271 & Primary Overheads Sample Station & $11 / 6 / 02$ & $3 \mathrm{H}$ & NP & 3000 & & & \\
\hline 300188272 & Alternate Overheads Sample Point \#1 & $11 / 6 / 02$ & $3 \mathrm{H}$ & NP & 3000 & & & \\
\hline 300188273 & Alternate Overheads Sample Point \#2 & $11 / 6 / 02$ & $3 \mathrm{H}$ & NP & 2600 & & & \\
\hline 300189349 & & $12 / 3 / 02$ & $3 \mathrm{H}$ & NP & 14000 & & & 9390 \\
\hline 300190443 & & $1 / 15 / 03$ & $3 \mathrm{H}$ & NP & 1500 & & & \\
\hline WSRC-018 & Primary Overheads Sample Station & $2 / 20 / 03$ & $3 \mathrm{H}$ & $\mathrm{HCl}$ & & & 2880 & 3700 \\
\hline WSRC-017 & Alternate Overheads Sample Point \#1 & $2 / 20 / 03$ & $3 \mathrm{H}$ & $\mathrm{HCl}$ & & & 4360 & 4520 \\
\hline $\mathrm{MeOH}-95$ & Primary Overheads Sample Station & $2 / 20 / 03$ & $3 \mathrm{H}$ & $\mathrm{MeOH}$ & 1960 & & & \\
\hline $\mathrm{MeOH}-94$ & Alternate Overheads Sample Point \#1 & $2 / 20 / 03$ & $3 \mathrm{H}$ & $\mathrm{MeOH}$ & 93.6 & & & \\
\hline 300192165 & & $2 / 20 / 03$ & $3 \mathrm{H}$ & NP & 490 & & & \\
\hline
\end{tabular}




\section{H Evaporator Vapor Results}

\author{
Sample Number \\ 021106-E3H-OHSC-DMHg-WT-4 \\ 021106-E3H-OHSC-STM-3 \\ 021106-E3H-OHRP1-DMHg-WT-3 \\ 021106-E3H-OHRP1-STM-2 \\ 021106-E3H-OHRP2-DMHg-WT-2 \\ 021106-E3H-OHRP2-STM-1 \\ 021106-E3H-MRB-DMHg-WT-5 \\ 021106-E3H-MRB-STM-4 \\ 021106-E3H-COCRD-DMHg -WT-6 \\ 021106-E3H-COCRD-STM-5 \\ 021106-E3H-OCS-DMHg-WT-7 \\ 021106-E3H-OCS-STM-6 \\ 021106-E3H-ORT1-DMHg-WT-8 \\ 021106-E3H-ORT1-STM-7 \\ 021106-E3H-ORT2-DMHg-WT-9 \\ 021106-E3H-ORT2-STM-8 \\ 021203-ORT1-DMHG-1 \\ 021203-ORT2-DMHG-2 \\ 021203-ORP1-DMHG-3 \\ 021203-ORP2-DMHG-4 \\ 021203-DMHG-5 \\ 021203-OCD-DMHG-6 \\ 021203-OCS-DMHG-7 \\ 021203-SVI-DMHG-8 \\ 11503-ORT1-DMHg-1 \\ 11503-ORT2-DMHg-2 \\ 11503-SVI-DMHg-3 \\ 11503-ORP1-DMHg-4A \\ 11503-ORP1-DMHg-4B \\ 11503-ORP2-DMHg-5A \\ 11503-ORP2-DMHg-5B \\ 030220-3HORT1-DMHg-1 \\ 030220-3HORT1-STM-1 \\ 030220-3HHg-DMHg-8 \\ 030220-3H Hg-STM-8 \\ 030220-3HDIKE-DMHg-3 \\ 030220-3HDIKE-STM-3 \\ 030220-3HPOH1-DMHg-4 \\ 030220-3HPOH1-STM-4 \\ 030220-3HORT2-DMHg-2 \\ 030220-3HORT2-STM-2 \\ 030220-3HSMP-DMHg-7 \\ 030220-3HSMP-STM-7 \\ 030220-3HAOH1-DMHg-5 \\ 030220-3HAOH1-STM-5
}

Location

Primary Overheads Sample Station Primary Overheads Sample Station Alternate Overheads Sample Point \#1 Alternate Overheads Sample Point \#1 Alternate Overheads Sample Point \#2 Alternate Overheads Sample Point \#2 Mercury Removal Station Mercury Removal Station General Area/Dike General Area/Dike

Overheads Cell Sump/Overheads Receiver Tanks Overflow Overheads Cell Sump/Overheads Receiver Tanks Overflow Overheads Receiver Tank \#1 Vent Overheads Receiver Tank \#1 Vent Overheads Receiver Tank \#2 Vent Overheads Receiver Tank \#2 Vent Overheads Receiver Tank \#2 Vent Overheads Receiver Tank \#1 Vent

Temporary Modification/Secondary Ventilation Interface Primary Overheads Sample Station Alternate Overheads Sample Point \#1 Alternate Overheads Sample Point \#2

Overheads Cell Sump/Overheads Receiver Tanks Overflow General Area/Dike

Overheads Receiver Tank \#1 Vent

Overheads Receiver Tank \#2 Vent

Temporary Modification/Secondary Ventilation Interface Alternate Overheads Sample Point \#1 Alternate Overheads Sample Point \#1 Alternate Overheads Sample Point \#2 Alternate Overheads Sample Point \#2 Overheads Receiver Tank \#1 Vent Overheads Receiver Tank \#1 Vent Primary Overheads Sample Station Primary Overheads Sample Station General Area/Dike General Area/Dike Mercury Removal Station Mercury Removal Station Overheads Receiver Tank \#2 Vent Overheads Receiver Tank \#2 Vent

Overheads Cell Sump/Overheads Receiver Tanks Overflow Overheads Cell Sump/Overheads Receiver Tanks Overflow Alternate Overheads Sample Point \#1 Alternate Overheads Sample Point \#1

\begin{tabular}{|c|c|c|c|c|}
\hline Date & Fac. & $\begin{array}{l}\mathrm{DMHg} \\
\mu \mathrm{g} / \mathrm{m}^{3}\end{array}$ & $\begin{array}{l}\text { EDMHg } \\
\mu \mathrm{g} / \mathrm{m}^{3}\end{array}$ & $\begin{array}{c}\mathrm{THg} \\
\mu \mathrm{g} / \mathrm{m}^{3}\end{array}$ \\
\hline $11 / 6 / 02$ & $3 \mathrm{H}$ & 1.88 & 1.88 & \\
\hline $11 / 6 / 02$ & $3 \mathrm{H}$ & & & 1.34 \\
\hline $11 / 6 / 02$ & $3 \mathrm{H}$ & 2.424 & 2.424 & \\
\hline $11 / 6 / 02$ & $3 \mathrm{H}$ & & & 6.4 \\
\hline $11 / 6 / 02$ & $3 \mathrm{H}$ & 0.737 & 0.737 & \\
\hline $11 / 6 / 02$ & $3 \mathrm{H}$ & & & 0.766 \\
\hline $11 / 6 / 02$ & $3 \mathrm{H}$ & 0.058 & 0.058 & \\
\hline $11 / 6 / 02$ & $3 \mathrm{H}$ & & & 0.472 \\
\hline $11 / 6 / 02$ & $3 \mathrm{H}$ & 0.168 & 0.168 & \\
\hline $11 / 6 / 02$ & $3 \mathrm{H}$ & & & 0.231 \\
\hline $11 / 6 / 02$ & $3 \mathrm{H}$ & 1.889 & 1.889 & \\
\hline $11 / 6 / 02$ & $3 \mathrm{H}$ & & & 1.48 \\
\hline $11 / 6 / 02$ & $3 \mathrm{H}$ & 12.065 & 12.065 & \\
\hline $11 / 6 / 02$ & $3 \mathrm{H}$ & & & 12.9 \\
\hline $11 / 6 / 02$ & $3 \mathrm{H}$ & 13.492 & 13.492 & \\
\hline $11 / 6 / 02$ & $3 \mathrm{H}$ & & & 228 \\
\hline $12 / 3 / 02$ & $3 \mathrm{H}$ & 0.02 & 0.02 & \\
\hline $12 / 3 / 02$ & $3 \mathrm{H}$ & $<0.02$ & 0.02 & \\
\hline $12 / 3 / 02$ & $3 \mathrm{H}$ & $<0.02$ & 0.02 & \\
\hline $12 / 3 / 02$ & $3 \mathrm{H}$ & 0.03 & 0.03 & \\
\hline $12 / 3 / 02$ & $3 \mathrm{H}$ & 138 & 138 & \\
\hline $12 / 3 / 02$ & $3 \mathrm{H}$ & 4.15 & 4.15 & \\
\hline $12 / 3 / 02$ & $3 \mathrm{H}$ & $<0.02$ & 0.02 & \\
\hline $12 / 3 / 02$ & $3 \mathrm{H}$ & $<0.02$ & 0.02 & \\
\hline $1 / 15 / 03$ & $3 \mathrm{H}$ & 3.11 & 3.11 & \\
\hline $1 / 15 / 03$ & $3 \mathrm{H}$ & 2.37 & 2.37 & \\
\hline $1 / 15 / 03$ & $3 \mathrm{H}$ & 0.14 & 0.14 & \\
\hline $1 / 15 / 03$ & $3 \mathrm{H}$ & 0.17 & 0.17 & \\
\hline $1 / 15 / 03$ & $3 \mathrm{H}$ & $>175$ & 350 & \\
\hline $1 / 15 / 03$ & $3 \mathrm{H}$ & 0 & 0 & \\
\hline $1 / 15 / 03$ & $3 \mathrm{H}$ & $>175$ & 350 & \\
\hline $2 / 20 / 03$ & $3 \mathrm{H}$ & 0.029 & 0.029 & \\
\hline $2 / 20 / 03$ & $3 \mathrm{H}$ & & & 1.17 \\
\hline $2 / 20 / 03$ & $3 \mathrm{H}$ & 0.015 & 0.015 & \\
\hline $2 / 20 / 03$ & $3 \mathrm{H}$ & & & 1.53 \\
\hline $2 / 20 / 03$ & $3 \mathrm{H}$ & 0.025 & 0.025 & \\
\hline $2 / 20 / 03$ & $3 \mathrm{H}$ & & & 0.9 \\
\hline $2 / 20 / 03$ & $3 \mathrm{H}$ & 0.005 & 0.005 & \\
\hline $2 / 20 / 03$ & $3 \mathrm{H}$ & & & 0.59 \\
\hline $2 / 20 / 03$ & $3 \mathrm{H}$ & 0.03 & 0.03 & \\
\hline $2 / 20 / 03$ & $3 \mathrm{H}$ & & & 1.3 \\
\hline $2 / 20 / 03$ & $3 \mathrm{H}$ & 0.048 & 0.048 & \\
\hline $2 / 20 / 03$ & $3 \mathrm{H}$ & & & 0.64 \\
\hline $2 / 20 / 03$ & $3 \mathrm{H}$ & 0.014 & 0.014 & \\
\hline $2 / 20 / 03$ & $3 \mathrm{H}$ & & & 0.33 \\
\hline
\end{tabular}


Wilmarth, et al.

WSRC-TR-2003-00238

Revision 1

\section{H Evaporator Liquid Results}

\begin{tabular}{|c|c|c|c|c|c|c|c|c|}
\hline Sample Number & Location & Date & Fac. & Pres. & DMHg & MMHG & TMHG & THg \\
\hline & & & & & $\boldsymbol{\mu g} / \mathbf{L}$ & $\boldsymbol{\mu g} / \mathbf{L}$ & $\boldsymbol{\mu g} / \mathbf{L}$ & $\boldsymbol{\mu g} / \mathbf{L}$ \\
\hline & & & & & & & & \\
\hline 300179674 & & $5 / 2 / 02$ & $2 \mathrm{H}$ & $\mathrm{NP}$ & 26 & & & \\
\hline WSRC-023 & Alternate Overheads Sample Point \#1 & $2 / 5 / 03$ & $2 \mathrm{H}$ & $\mathrm{HCl}$ & & & 2692 & 1014 \\
\hline MeOH-04 & Alternate Overheads Sample Point \#1 & $2 / 5 / 03$ & $2 \mathrm{H}$ & $\mathrm{MeOH}$ & 1137 & & & \\
\hline WSRC-021 & Alternate Overheads Sample Point \#2 & $2 / 5 / 03$ & $2 \mathrm{H}$ & $\mathrm{HCl}$ & & & 4513 & 1276 \\
\hline MeOH-40 & Alternate Overheads Sample Point \#2 & $2 / 5 / 03$ & $2 \mathrm{H}$ & $\mathrm{MeOH}$ & 2193 & & & \\
\hline WSRC-028 & Blank HCL & $2 / 5 / 03$ & & & & & $2 \mathrm{E}-07$ & 0.0000149 \\
\hline WSRC-053 & Blank HCL & $2 / 5 / 03$ & & & & & $9 \mathrm{E}-07$ & 0.0000164 \\
\hline MeOH-82 & Primary Overheads Sample Station & $2 / 20 / 03$ & $2 \mathrm{H}$ & $\mathrm{MeOH}$ & 15.1 & & & \\
\hline MeOH-06 & Primary Overheads Sample Station & $2 / 20 / 03$ & $2 \mathrm{H}$ & $\mathrm{MeOH}$ & 14.1 & & & \\
\hline MeOH-11 & Primary Overheads Sample Station & $2 / 20 / 03$ & $2 \mathrm{H}$ & $\mathrm{MeOH}$ & 14.8 & & & \\
\hline WSRC-048 & Primary Overheads Sample Station & $2 / 20 / 03$ & $2 \mathrm{H}$ & $\mathrm{HCl}$ & & & 2120 & 2340 \\
\hline WSRC-05 & Primary Overheads Sample Station & $2 / 20 / 03$ & $2 \mathrm{H}$ & $\mathrm{HCl}$ & & & 2260 & 2330 \\
\hline WSRC-027 & Primary Overheads Sample Station & $2 / 20 / 03$ & $2 \mathrm{H}$ & $\mathrm{HCl}$ & & & 2080 & 2300 \\
\hline 300192164 & & $2 / 20 / 03$ & $2 \mathrm{H}$ & $\mathrm{NP}$ & 220 & & & \\
\hline MeOH-100 & Primary Overheads Sample Station & $3 / 4 / 03$ & $2 \mathrm{H}$ & $\mathrm{MeOH}$ & 957 & & & \\
\hline WSRC-024 & Primary Overheads Sample Station & $3 / 4 / 03$ & $2 \mathrm{H}$ & $\mathrm{HCl}$ & & & 2679 & 2932 \\
\hline MeOH-101 & Alternate Overheads Sample Point \#1 & $3 / 4 / 03$ & $2 \mathrm{H}$ & $\mathrm{MeOH}$ & 1226 & & & \\
\hline WSRC-055 & Alternate Overheads Sample Point \#1 & $3 / 4 / 03$ & $2 \mathrm{H}$ & $\mathrm{HCl}$ & & & 3190 & 3134 \\
\hline MeOH-102 & Alternate Overheads Sample Point \#2 & $3 / 4 / 03$ & $2 \mathrm{H}$ & $\mathrm{MeOH}$ & 1500 & & \\
\hline WSRC-046 & Alternate Overheads Sample Point \#2 & $3 / 4 / 03$ & $2 \mathrm{H}$ & $\mathrm{HCl}$ & & 3109 & 3374 \\
\hline
\end{tabular}




\section{H Evaporator Vapor Results}

Sample Number

030205-2HORT-DMHg-1
030205-2HAOH1-DMHg-4
030205-2HAOH2-DMHg-5
030205-2HOF-DMHg-6
030205-2HHg-DMHg-7
030205-2HORT-STM-1
030205-2HAOH1-STM-4
030205-2HAOH2-STM-5
030205-2HOF-STM-6
030205-2HHg-STM-7
030220-2HPOH-DMHg-1
030220-2H-POH-STM-1
030304-2HOF-DMHg-1
030304-2HOF-STM-1
030304-2HDIKE-DMHg-2
030304-2HDIKE-STM-2
030304-2HHEPA-DMHg-3
030304-2HHEPA-STM-3
030304-2HSUMP-DMHg-4
030304-2HSUMP-STM-4

Location

Between Overheads Receiver Tanks HEPAs
Alternate Overheads Sample Point \#1
Alternate Overheads Sample Point \#2
Overheads Cell Sump/Overheads Receiver Tanks Overflow
Mercury Removal Station
Between Overheads Receiver Tanks HEPAs
Alternate Overheads Sample Point \#1
Alternate Overheads Sample Point \#2
Mercury Removal Station
Overheads Cell Sump/Overheads Receiver Tanks Overflow
Primary Overheads Sample Station
Overheads Cell Sump/Overheads Receiver Tanks Overflow
Overheads Cell Sump/Overheads Receiver Tanks Overflow
General Area/Dike
General Area/Dike
Between Overheads Receiver Tanks HEPAs
Between Overheads Receiver Tanks HEPAs
Overheads Cell Sump/Overheads Receiver Tanks Overflow
Overheads Cell Sump/Overheads Receiver Tanks Overflow

Date


$2 / 5 / 03$
$2 / 5 / 03$
$2 / 5 / 03$
$2 / 5 / 03$
$2 / 5 / 03$
$2 / 5 / 03$
$2 / 5 / 03$
$2 / 5 / 03$
$2 / 5 / 03$
$2 / 5 / 03$
$2 / 20 / 03$
$2 / 20 / 03$
$3 / 4 / 03$
$3 / 4 / 03$
$3 / 4 / 03$
$3 / 4 / 03$
$3 / 4 / 03$
$3 / 4 / 03$
$3 / 4 / 03$
$3 / 4 / 03$

Fac.

$\mathrm{DMHg}$

EDMHg $\mu \mathrm{g} / \mathrm{m}^{3}$

THg $\mu \mathrm{g} / \mathrm{m}^{3}$

$2 \mathrm{H} \quad>0.28 \quad 1.7$

$2 \mathrm{H}>7.8 \quad 14$

$2 \mathrm{H}>7.8 \quad 18$

$2 \mathrm{H} \quad>7.8 \quad 185$

$\begin{array}{lll}2 \mathrm{H} & 4.61 & 4.61\end{array}$

$2 / 5 / 03 \quad 2 \mathrm{H}$

$15 / 03 \quad 2 \mathrm{H}$

$4.61 \quad 4.61$

35.7

34.6

199

259

4.06

$1.52 \quad 1.52$

0.88

$>89.4 \quad 360$

930

$>89.4 \quad 180$

137

$36.9 \quad 36.9$

52

$>89.4 \quad 360$

813 


\section{F Evaporator Liquid Results}

\begin{tabular}{|c|c|c|c|c|c|}
\hline Sample Number & Location & Date & DMHg & TMHG & THg \\
\hline & & & $\boldsymbol{\mu g} / \mathbf{L}$ & $\boldsymbol{\mu g} / \mathbf{L}$ & $\boldsymbol{\mu g} / \mathbf{L}$ \\
\hline & & & & & \\
\hline 300179675 & & $5 / 2 / 02$ & $<2$ & & \\
\hline WSRC-014 & Primary Overheads Sample Station & $2 / 4 / 03$ & & $16.2 / 29.8$ & 3014 \\
\hline WSRC-020 & Alternate Overheads Sample Point \#2 & $2 / 4 / 03$ & & $15.8 / 23.6$ & 515 \\
\hline WSRC-025 & Alternate Overheads Sample Point \#1 & $2 / 4 / 03$ & & $11.9 / 22.3$ & 449 \\
\hline MeOH-10 & Alternate Overheads Sample Point \#2 & $2 / 4 / 03$ & 2.63 & & \\
\hline MeOH-2 & Primary Overheads Sample Station & $2 / 4 / 03$ & 1.53 & & \\
\hline MeOH-16 & Alternate Overheads Sample Point \#1 & $2 / 4 / 03$ & 1.28 & & \\
\hline 300191577 & & $2 / 4 / 03$ & 1.3 & & \\
\hline WSRC-044 & Primary Overheads Sample Station & $2 / 19 / 03$ & & 32.6 & 221 \\
\hline WSRC-016 & Primary Overheads Sample Station & $2 / 19 / 03$ & & 32.5 & 188 \\
\hline WSRC-039 & Primary Overheads Sample Station & $2 / 19 / 03$ & & 30.5 & 186 \\
\hline MeOH-98 & Primary Overheads Sample Station & $2 / 19 / 03$ & $1.96,2.33$ & & \\
\hline MeOH-15 & Primary Overheads Sample Station & $2 / 19 / 03$ & 2.02 & & \\
\hline MeOH-60 & Primary Overheads Sample Station & $2 / 19 / 03$ & 1.96 & & \\
\hline 300192166 & & $2 / 19 / 03$ & $<10$ & & \\
\hline WSRC-034 & Primary Overheads Sample Station & $3 / 5 / 03$ & & 24.4 & 196 \\
\hline MeOH-103 & Primary Overheads Sample Station & $3 / 5 / 03$ & 2.33 & & \\
\hline WSRC-037 & Alternate Overheads Sample Point \#1 & $3 / 5 / 03$ & & 13.6 & 4247 \\
\hline MeOH-104 & Alternate Overheads Sample Point \#1 & $3 / 5 / 03$ & 1.35 & & \\
\hline WSRC-045 & Alternate Overheads Sample Point \#2 & $3 / 5 / 03$ & & 0.475 & 612 \\
\hline MeOH-105 & Alternate Overheads Sample Point \#2 & $3 / 5 / 03$ & 0.0018 & & \\
\hline
\end{tabular}

\section{F Evaporator Vapor Results}

\begin{tabular}{|c|c|c|c|c|}
\hline Sample Number & Location & Date & DMHg & THg \\
\hline & & & $\mu \mathrm{g} / \mathrm{m}^{3}$ & $\mu \mathrm{g} / \mathrm{m}^{3}$ \\
\hline & & & & \\
\hline 030305-2FSUMP-DMHg-1 & Overheads Cell Sump/Overheads Receiver Tanks Overflow & $3 / 5 / 03$ & 0.734 & \\
\hline 030305-2FSUMP-STM-1 & Overheads Cell Sump/Overheads Receiver Tanks Overflow & $3 / 5 / 03$ & & 1.84 \\
\hline 030305-2FDIKE-DMHg-2 & General Area/Dike & $3 / 5 / 03$ & 0.101 & \\
\hline 030305-2FDIKE-STM-2 & General Area/Dike & $3 / 5 / 03$ & & 17.2 \\
\hline 030305-2FPRIM-DMHg-3 & Primary Overheads Sample Station & $3 / 5 / 03$ & 0.039 & \\
\hline 030305-2FPRIM-STM-3 & Primary Overheads Sample Station & $3 / 5 / 03$ & & 1.09 \\
\hline 030305-2FALT1-DMHg-4 & Alternate Overheads Sample Point \#1 & $3 / 5 / 03$ & 0.012 & \\
\hline 030305-2FALT1-STM-4 & Alternate Overheads Sample Point \#1 & $3 / 5 / 03$ & & 0.254 \\
\hline 030305-2FALT2-DMHg-5 & Alternate Overheads Sample Point \#2 & $3 / 5 / 03$ & $<0.004$ & \\
\hline 030305-2FALT2-STM-5 & Alternate Overheads Sample Point \#2 & $3 / 5 / 03$ & & 0.356 \\
\hline 030305-2FHg-DMHg-6 & Mercury Removal Station & $3 / 5 / 03$ & $<0.004$ & \\
\hline 030305-2FHg-STM-6 & Mercury Removal Station & $3 / 5 / 03$ & & 0.135 \\
\hline
\end{tabular}


Wilmarth, et al.

WSRC-TR-2003-00238

Revision 1

Effluent Treatment Facility Liquid Results

\begin{tabular}{|c|c|c|c|c|c|c|c|c|}
\hline Sample Number & Location & Date & Fac. & Pres. & DMHg & MMHG & TMHG & THg \\
\hline & & & & & $\mu \mathrm{g} / \mathrm{L}$ & $\mu g / L$ & $\mu g / L$ & $\mu g / L$ \\
\hline & & & & & & & & \\
\hline 300189423 & H-Lift Station Sample Station & $12 / 17 / 02$ & ETF & NP & $<1$ & & & \\
\hline WSRC-038 & IX Effluent Sample Point & $1 / 31 / 03$ & ETF & $\mathrm{HCl}$ & & & 0.0013 & 0.418 \\
\hline $\mathrm{MeOH}-23$ & IX Effluent Sample Point & $1 / 31 / 03$ & ETF & $\mathrm{MeOH}$ & $<0.1$ & & & \\
\hline WSRC-019 & H-Lift Station Sample Station & $2 / 6 / 03$ & ETF & $\mathrm{HCl}$ & & & 547.3 & 97.9 \\
\hline $\mathrm{MeOH}-99$ & H-Lift Station Sample Station & $2 / 6 / 03$ & ETF & $\mathrm{MeOH}$ & 0.92 & & & \\
\hline WSRC-022 & F-Lift Station Sample Station & $2 / 6 / 03$ & ETF & $\mathrm{HCl}$ & & & 6 & 93.6 \\
\hline $\mathrm{MeOH}-17$ & F-Lift Station Sample Station & $2 / 6 / 03$ & ETF & $\mathrm{MeOH}$ & 0.05 & & & \\
\hline $\mathrm{MeOH}-97$ & IX Effluent Sample Point & $2 / 19 / 03$ & ETF & $\mathrm{MeOH}$ & 0.023 & & & \\
\hline WSRC-032 & IX Effluent Sample Point & $2 / 19 / 03$ & ETF & $\mathrm{HCl}$ & & & 0.0004 & 0.0659 \\
\hline WSRC-015 & H-Lift Station Sample Station & $2 / 19 / 03$ & ETF & $\mathrm{HCl}$ & & & 910,1065 & 28200 \\
\hline $\mathrm{MeOH}-13$ & H-Lift Station Sample Station & $2 / 19 / 03$ & ETF & $\mathrm{MeOH}$ & 96.7 & & & \\
\hline $\mathrm{MeOH}-96$ & F-Lift Station Sample Station & $2 / 19 / 03$ & ETF & $\mathrm{MeOH}$ & $\mathrm{ND}(<0.002)$ & & & \\
\hline WSRC-013 & F-Lift Station Sample Station & $2 / 19 / 03$ & ETF & $\mathrm{HCl}$ & & & 0.548 & 387 \\
\hline WSRC-040 & Waste Water Collection Tank Sample Point & $3 / 13 / 03$ & ETF & $\mathrm{HCl}$ & & & 369 & 455 \\
\hline MeOH-199 & Waste Water Collection Tank Sample Point & $3 / 13 / 03$ & ETF & $\mathrm{MeOH}$ & 12.1 & & & \\
\hline
\end{tabular}

Vapor Results

\begin{tabular}{|c|c|c|c|c|c|c|}
\hline Sample Number & Location & Date & Fac. & DMHg & EDMHg & $\mathrm{THg}$ \\
\hline & & & & $\mu \mathrm{g} / \mathrm{m}^{3}$ & $\mu \mathrm{g} / \mathrm{m}^{3}$ & $\mu \mathrm{g} / \mathrm{m}^{3}$ \\
\hline 030211-ETPCC2-DMHa-1 & Carbon Column \#2 Manway & $2 / 11 / 03$ & ETF & 0047 & 0047 & \\
\hline 030211-ETPCC2-STM-1 & Carbon Column \#2 Manway & $2 / 11 / 03$ & ETF & & & \\
\hline 030211-ETPSMP-DMHg-3 & Carbon Columns Sump & $2 / 11 / 03$ & ETF & $<0.0011$ & 0.0011 & \\
\hline 030211-ETPSMP-STM-3 & Carbon Columns Sump & $2 / 11 / 03$ & ETF & & & 0.73 \\
\hline 030212-ETPHg-DMHg-1 & Mercury Column \#1 Manway & $2 / 12 / 03$ & ETF & 0.016 & 0.016 & \\
\hline 030212-ETPHg-STM-1 & Mercury Column \#1 Manway & $2 / 12 / 03$ & ETF & & & 34.3 \\
\hline 030219-HLS-DMHg-1 & H-Lift Station Manhole & $2 / 19 / 03$ & ETF & 4.84 & 4.84 & \\
\hline 030219-HLS-STM-1 & H-Lift Station Manhole & $2 / 19 / 03$ & ETF & & & 0.03 \\
\hline 030219-FLS-DMHg-2 & F-Lift Station Manhole & $2 / 19 / 03$ & ETF & $<0.080$ & 0.08 & \\
\hline 030219-FLS-STM-2 & F-Lift Station Manhole & $2 / 19 / 03$ & ETF & & & 0.01 \\
\hline 030219-HLV-DMHg-4 & H-Lift Station Ventilation Exhaust & $2 / 19 / 03$ & ETF & $>82$ & 165 & \\
\hline 030225-ETP1HgCSMP-DMHg-1 & Carbon Columns Sump & $2 / 25 / 03$ & ETF & $>89.4$ & 180 & \\
\hline 030225-ETP1HgCSMP-DMHg-2 & Carbon Columns Sump & $2 / 25 / 03$ & ETF & $>89.4$ & 180 & \\
\hline 030313-ETPWWCT-DMHg-1 & Waste Water Collection Tank Sample Point & $3 / 13 / 03$ & ETF & 0.344 & 0.344 & \\
\hline 030313-ETPWWCT-STM-1 & Waste Water Collection Tank Sample Point & $3 / 13 / 03$ & ETF & & & 0.178 \\
\hline 030313-ETPWCT-DMHg-2 & Waste Concentrate Sample Point & $3 / 13 / 03$ & ETF & $<0.004$ & 0.004 & \\
\hline 030313-ETPWCT-STM-2 & Waste Concentrate Sample Point & $3 / 13 / 03$ & ETF & & & 0.074 \\
\hline 030313-ETPHLSV-DMHg-3 & H-Lift Station Ventilation Exhaust & $3 / 13 / 03$ & ETF & $>89.4$ & 180 & \\
\hline 030313-ETPHLSV-STM-3 & H-Lift Station Ventilation Exhaust & $3 / 13 / 03$ & ETF & & & 222 \\
\hline
\end{tabular}

Page 31 of 33 
This page was intentionally left blank 


\section{REFERENCES}

\footnotetext{
${ }^{1}$ P. Davis , Task Technical Request, “3H Evaporator Support for Fate of Mercury,” HLE-TTR-2003-031, Rev. 0, October 30, 2002.

${ }^{2}$ P. D. d'Entremont, "Functions and Requirements for the $2 \mathrm{H}$ and $3 \mathrm{H}$ Evaporator Flowsheet Models," HLW-PRE-2001-0003, November 15, 2001.

${ }^{3}$ D. R. Lide, Editor, CRC Handbook of Chemistry and Physics, $71^{\text {st }}$ Edition, CRC Press.

${ }^{4}$ Statistical Consulting Section, "Software Verification and Validation for Commercial Statistical Packages Utilized by the Statistical Consulting Section of SRTC,” WSRC-RP-99-00422, Rev. 0, May 21, 1999.

${ }^{5}$ G. Fuseya, “The Solubility of Mercuric Oxide in Sodium Hydroxide Solutions,” J. AM. Chem. Soc. (1920) 42, 368.

${ }^{6}$ J. P. Bibler, “Solubility Versus pH of Selected Metals .... Response”, IWT-LWP-89-0814, January 3, 1984.

${ }^{7}$ Zhou and Chen, Fudan Xuebao, Ziran Kexueban (1983) 22, 229.

${ }^{8}$ J. P. Bibler, "Mercury Volatility in the Presence of Reducing Agents,” DPST-86-333, March 13, 1986.

${ }^{9}$ S. W. Rosencrance and W. R. Wilmarth, "Initial Analysis Results for 3H Evaporator Overheads by Frontier Geosciences,” SRT-LWP-2002-00052. May 17, 2002.

${ }^{10}$ S. W. Rosencrance and W. R. Wilmarth, "Approaches to Calculation of Dimethylmercury in Air," SRTLWP-2002-00048, May 9, 2002.

${ }^{11}$ D. W. Rochelle, "2F, 2H and 3H Evaporator and ETF Mercury/Organo (Alkyl) Mercury Pathforward," CBU-HDP-2003-00009, January 03, 2003.

${ }^{12}$ E-Mail, E. Prestbo to D. Thaxton, et. al., “3H and Tank DMHg and STM Results, dated June 3, 2003.

${ }^{13}$ E. Prestbo, J. Garcia, P. Swartzendruber, E. von der Geest, and S. Rosencrance, "Evaluation of the Potential for Chemical Formation of Dimethyl Mercury at High pH in the Presence of Selected Organics,” January 9, 2003.

${ }^{14}$ D. D. Walker, “Organic compounds in Savannah River High-Level Waste,” WSRC-TR-2002-00391, rev. 0, September 30, 2002.

${ }^{15}$ E. Presbo, J. Garcia, E. von der Geest, and S. Rosencrance, "Evaluation of the Potential for Chemical Formation of Dimethyl Mercury at High pH in the Presence of Selected Organics,” Frontier Geosciences, Seattle, WA, January 9, 2003.

${ }^{16}$ Formation of $\left(\mathrm{CH}_{3}\right)_{2} \mathrm{Hg}$ in Simulated Waste Tank Solutions, Frontier Geosciences, Seattle, WA, December 8, 2003.

${ }^{17}$ N. S. Bloom, “Dimethyl Mercury Degradation Experiments," Frontier Geosciences, Seattle, WA, December 8, 2003.
} 